Article

\title{
Antiproliferative S-Trityl-L-Cysteine -Derived Compounds as SIRT2 Inhibitors: Repurposing and Solubility Enhancement
}

\author{
Mohamed O. Radwan ${ }^{1,2,3\left(\mathbb{D}, \text { Halil I. Ciftci }{ }^{1,2} \text { (), Taha F. S. Ali }\right.}{ }^{2,4}$, Doha E. Ellakwa ${ }^{2,5}$ (D, \\ Ryoko Koga ${ }^{2}$, Hiroshi Tateishi ${ }^{2}$, Akiko Nakata ${ }^{6}$, Akihiro Ito ${ }^{7,8}$, Minoru Yoshida ${ }^{6,7,9}$, \\ Yoshinari Okamoto ${ }^{2}$, Mikako Fujita ${ }^{2, *}$ and Masami Otsuka ${ }^{1,2, *}$ \\ 1 Department of Drug Discovery, Science Farm Ltd., 1-7-30-805 Kuhonji, Chuo-Ku, Kumamoto 8620976, Japan \\ 2 Medicinal and Biological Chemistry Science Farm Joint Research Laboratory, Faculty of Life Sciences, \\ Kumamoto University, 5-1 Oe-honmachi, Chuo-Ku, Kumamoto 8620973, Japan \\ 3 Chemistry of Natural Compounds Department, Pharmaceutical and Drug Industries Research Division, \\ National Research Centre, Dokki, Cairo 12622, Egypt \\ 4 Medicinal Chemistry Department, Faculty of Pharmacy, Minia University, Minia 61519, Egypt \\ 5 Department of Biochemistry Science, Faculty of Pharmacy, Al-Azhar University (Girls), Nasr City, Cairo 11651, Egypt \\ 6 Seed Compounds Exploratory Unit for Drug Discovery Platform, RIKEN Center for Sustainable Resource \\ Science, 2-1 Hirosawa, Wako, Saitama 3510198, Japan \\ 7 Chemical Genomics Research Group, RIKEN Center for Sustainable Resource Science, 2-1 Hirosawa, Wako, \\ Saitama 3510198, Japan \\ 8 School of Life Sciences, Tokyo University of Pharmacy and Life Sciences, 1432-1 Horinouchi, Hachioji, \\ Tokyo 1920392, Japan \\ 9 Department of Biotechnology, Graduate School of Agricultural and Life Sciences, The University of Tokyo, \\ 1-1-1 Yayoi, Bunkyo-ku, Tokyo 1138657, Japan \\ * Correspondence: mfujita@kumamoto-u.ac.jp (M.F.); motsuka@gpo.kumamoto-u.ac.jp (M.O.); \\ Tel.: +81-096-371-4622 (M.F. \& M.O.)
}

Academic Editors: Nazim Sekeroglu, Anake Kijjoa and Sevgi Gezici

Received: 29 July 2019; Accepted: 6 September 2019; Published: 10 September 2019

check for updates

\begin{abstract}
S-trityl-L-cysteine (STLC) is a well-recognized lead compound known for its anticancer activity owing to its potent inhibitory effect on human mitotic kinesin Eg5. STLC contains two free terminal amino and carboxyl groups that play pivotal roles in binding to the Eg5 pocket. On the other hand, such a zwitterion structure complicates the clinical development of STLC because of the solubility issues. Masking either of these radicals reduces or abolishes STLC activity against Eg5. We recently identified and characterized a new class of nicotinamide adenine dinucleotide-dependent deacetylase isoform 2 of sirtuin protein (SIRT2) inhibitors that can be utilized as cytotoxic agents based on an S-trityl-L-histidine scaffold. Herein, we propose new STLC-derived compounds that possess pronounced SIRT2 inhibition effects. These derivatives contain modified amino and carboxyl groups, which conferred STLC with SIRT2 bioactivity, representing an explicit repurposing approach. Compounds STC4 and STC11 exhibited half maximal inhibitory concentration values of $10.8 \pm 1.9$ and $9.5 \pm 1.2 \mu \mathrm{M}$, respectively, against SIRT2. Additionally, introduction of the derivatizations in this study addressed the solubility limitations of free STLC, presumably due to interruption of the zwitterion structure. Therefore, we could obtain drug-like STLC derivatives that work by a new mechanism of action. The new derivatives were designed, synthesized, and their structure was confirmed using different spectroscopic approaches. In vitro and cellular bioassays with various cancer cell lines and in silico molecular docking and solubility calculations of the synthesized compounds demonstrated that they warrant attention for further refinement of their bioactivity.
\end{abstract}

Keywords: STLC; SIRT2; anticancer; molecular docking; solubility 


\section{Introduction}

S-trityl-L-cysteine (STLC) (Figure 1) has been identified as an ATP-noncompetitive and reversible inhibitor of human mitotic kinesin Eg5 with potential as an antimitotic chemotherapeutic agent [1-4]. STLC has also been reported as a potent anticancer agent in an NCI 60 tumor cell line screen (half maximal tumor growth inhibition concentration of $1.3 \mu \mathrm{M}$ ). It was listed as one of 171 molecules with a "particularly high level of interest at the NCI" in the NCI database of standard agents [5]. STLC development has been hindered by pharmacokinetic issues, whereas other kinesin Eg5 inhibitors from different chemical classes have already entered clinical trials. The quinazolinone derivative ispinesib was the first Eg5 inhibitor to enter phase I and phase II clinical trials and to be tested for its cytotoxic activity in patients with various tumors [6]. This was followed by more potent clinical candidates such as AZD4877, litronesib, and EMD544085 [7-9]. The amphiphilic character of STLC results in poor water solubility and reduced permeability that affect its bioavailability [10]. Unfortunately, addressing this issue by alkylation or acylation of the STLC free primary amine resulted in loss of activity [4]. There are many known inhibitors of Eg5 that lack a primary amine group and still have good affinity, whereas this seems to be a prerequisite for derivatives of STLC $[4,11]$. Moreover, the absence of the carboxyl group leads to an approximately $30 \%$ reduction in activity compared with the parent compound [11,12]. Modification of the carboxylic acid terminal to a primary amide or a methyl ester also reduced Eg5 ATPase activity, albeit it with reduced cellular toxicity, presumably by enhancing STLC cell permeation ${ }^{4}$. The co-crystal structure revealed polar interactions formed between the amine group of STLC with Glu116 and Gly117 and between its carboxyl group and Arg221 (Figure 1) [13,14]. Free ionized primary amine and carboxyl groups give the highest contribution to the binding of charged amino acids at physiological $\mathrm{pH}$ [15]. As a rationale, modification of the STLC primary amine and carboxyl groups for better pharmacokinetics may necessitate repurposing towards another valid target because such modifications may compromise its Eg5 ATPase inhibition effect.

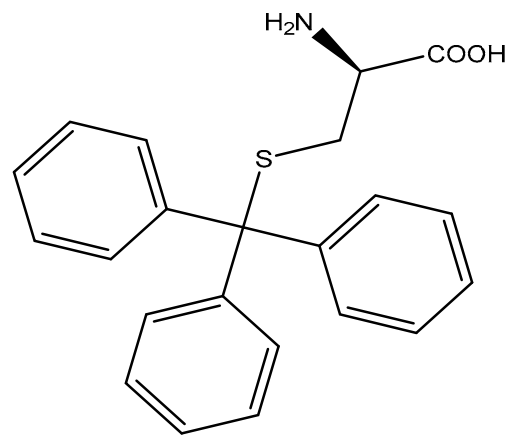

(A)

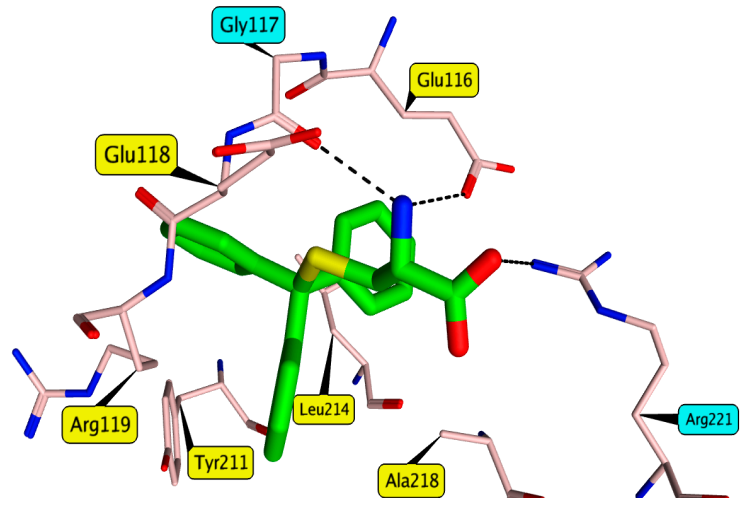

(B)

Figure 1. (A) S-trityl-l-cysteine (STLC) structure. (B) Binding interactions of STLC (green, PDB 3KEN) within Eg5 (cyan) showing the pivotal role of the free ionized amine and carboxyl groups.

Nicotinamide adenine dinucleotide-dependent deacetylase isoform 2 of sirtuin protein (SIRT2) is a member of the sirtuins family, which deacetylates lysine residues on histones as well as key transcriptional factors, such as p53 and NF- $\mathrm{kB}$ [16-18], and cytoskeletal proteins $\alpha$-tubulin and cortactin $[19,20]$. It participates in the modulation of multiple biological processes including cell cycle control, genomic integrity, microtubule dynamics, cell differentiation, DNA repair, autophagy, and pathological processes such as tumorigenesis, neurodegeneration, survival, and drug resistance of cancer cells [21-23]. SIRT2 inhibitors showed antiproliferative effects against different cancer cell lines such as luminal and triple-negative breast cancers [22,24], leukemia of different genotypes [24-27], and cervical cancer [28]. Recently, we have identified and characterized a new class of potent and selective SIRT2 inhibitors; the lead compound, TH-3, has a half maximal inhibitory concentration $\left(\mathrm{IC}_{50}\right)$ of 
$1.3 \mu \mathrm{M}$ [29]. With its trityl histidine scaffold, TH-3 shares features in common with the reported SIRT2 inhibitor SirReal2 $\left(\mathrm{IC}_{50}=0.21 \mu \mathrm{M}\right)$ [30]. Based on our previous findings, we sought to design STLC-like compounds incorporating different substitutions on the primary amine group that may imitate the trityl histidine structure. This study aimed to confer STLC with novel bioactivities against SIRT2 by enhancing its pharmacokinetic profile via modification of its terminal amine and carboxyl groups.

\section{Results and Discussion}

The designs of the new STLC derivatives were based on TH-3 by conserving its trityl group, whereas the L-histidine moiety was replaced by L-cysteine. To obtain exhaustive structure-activity relationship (SAR) information, the amino group was reductively alkylated or acylated using different substituted aldehydes and acyl chlorides, respectively. The terminal methyl ester group was kept or converted to hydrazide (Figure 2). The synthetic procedures were initiated by STLC esterification using thionyl chloride and methanol to obtain compound $\mathbf{1}$ at a quantitative yield. Reductive alkylation of $\mathbf{1}$ was achieved using different commercial aldehydes in the presence of sodium triacetoxy borohydride, affording compounds STC1-9 with moderate yields (Scheme 1). Two noncommercially available aldehydes, 4-(dimethylamino)picolinaldehyde and 4-(diethylamino)picolinaldehyde, were prepared as described previously [31-33]. Thereafter, the in vitro SIRT2 inhibitory activities of these synthesized compounds were examined using electrophoretic mobility shift assays [29] (Table 1).

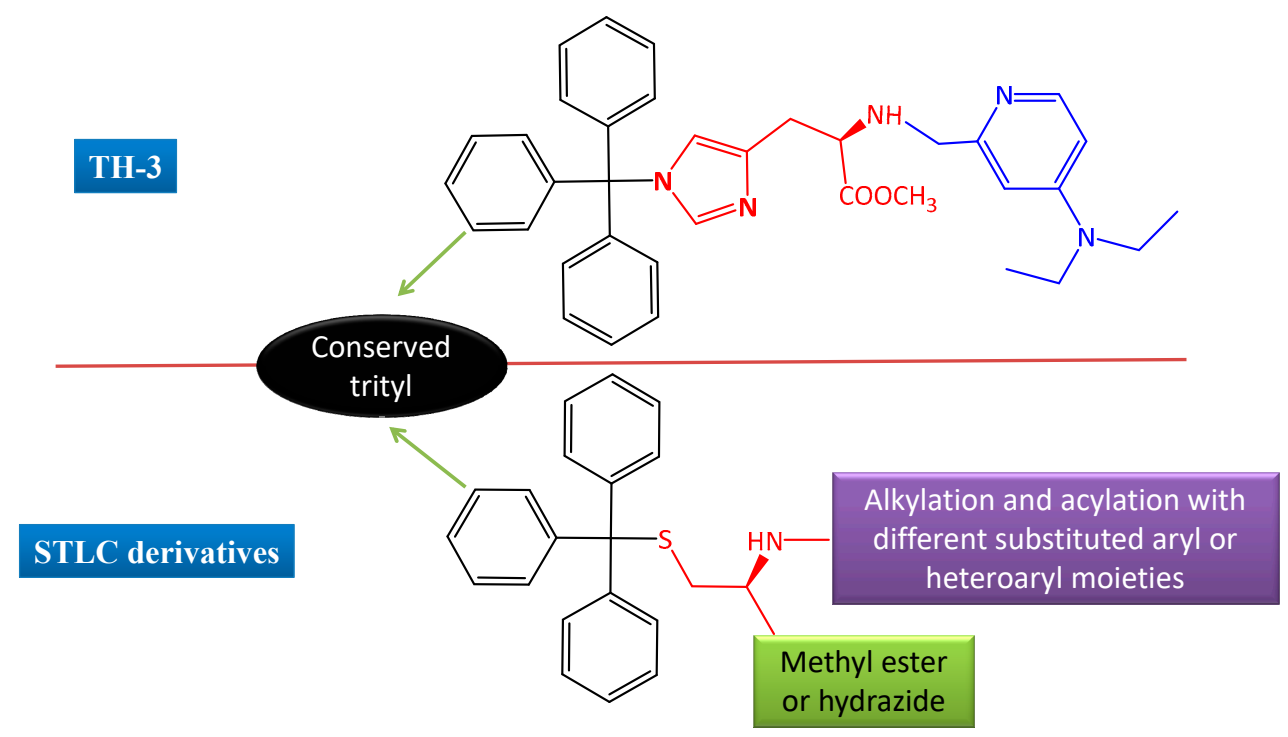

Figure 2. Design of new STLC derivatives targeting SIRT2 based on compound TH-3 $\left(\mathrm{IC}_{50}\right.$ against SIRT2 $=1.3 \mu \mathrm{M})[29]$.

Table 1. In vitro inhibitory activity of STLC derivatives against SIRT2.

\begin{tabular}{cccc}
\hline Compound & $\begin{array}{c}\mathrm{IC}_{\mathbf{5 0}} \text { against SIRT2 } \\
(\boldsymbol{\mu} \mathbf{M})\end{array}$ & Compound & $\begin{array}{c}\mathrm{IC}_{\mathbf{5 0}} \text { against SIRT2 } \\
(\boldsymbol{\mu} \mathbf{M})\end{array}$ \\
\hline $\mathbf{1}$ & $>100$ & STC7 & $>100$ \\
STC1 & $>100$ & STC8 & $>100$ \\
STC2 & $>100$ & STC9 & $17.2 \pm 1.2$ \\
STC3 & $>100$ & STC10 & $>100$ \\
STC4 & $10.8 \pm 1.9$ & STC11 & $9.5 \pm 1.2$ \\
STC5 & $>100$ & TH-3 & $1.3 \pm 0.2$ \\
STC6 & $>100$ & & \\
\hline
\end{tabular}



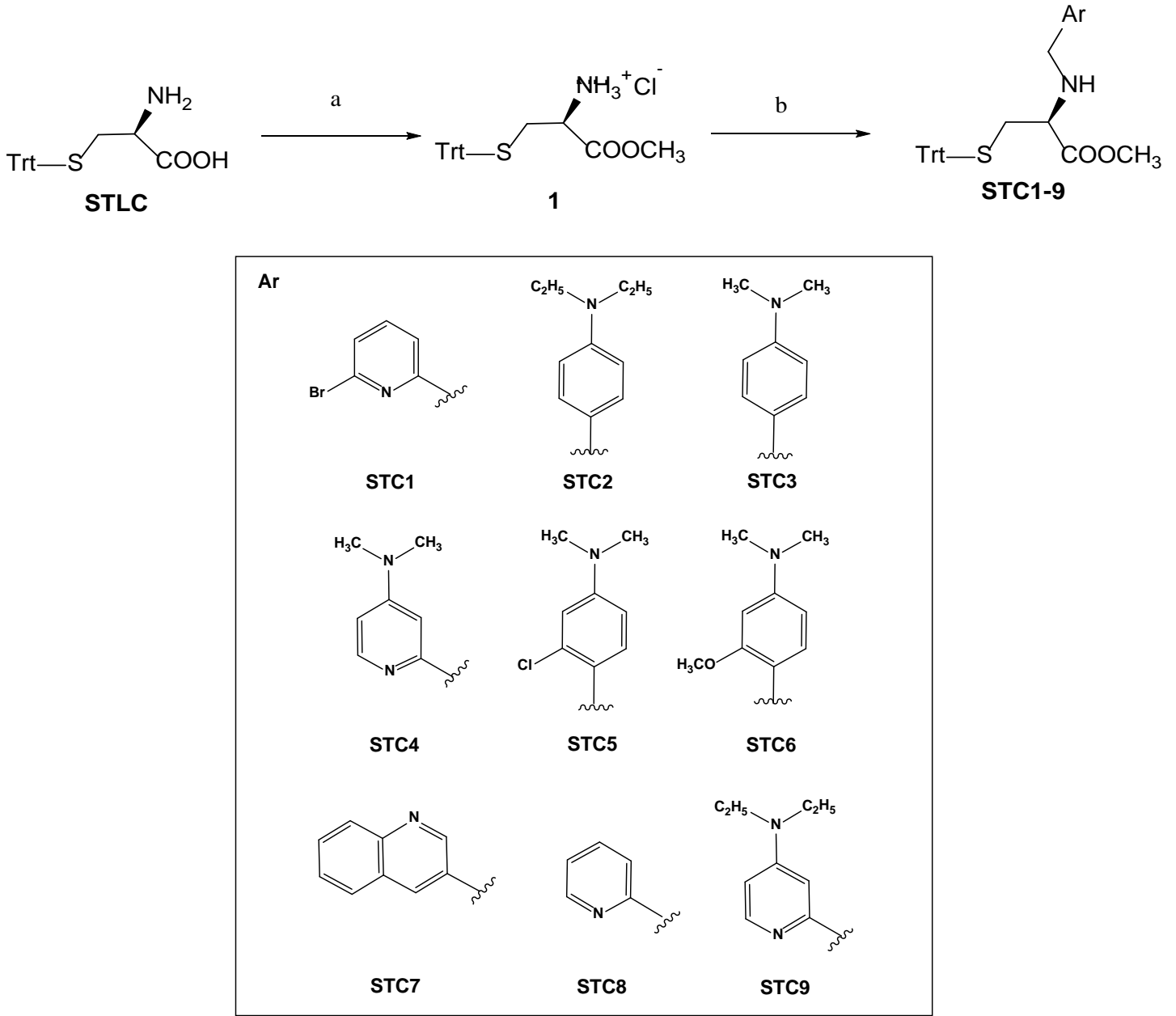

Scheme 1. ${ }^{\text {a }} \mathrm{SOCl}_{2}, \mathrm{MeOH} ;{ }^{\mathrm{b}} \mathrm{Ar}-\mathrm{CHO}, \mathrm{NaBH}(\mathrm{OAc})_{3}$, room temperature $3 \mathrm{~h}$.

The parent compound 1 (STLC methyl ester) was inactive against SIRT2. Compound STC4, with an $N, N$-dimethyl aminopyridyl moiety, demonstrated strong SIRT2 inhibition in vitro $\left(\mathrm{IC}_{50}=\right.$ $10.8 \pm 1.9 \mu \mathrm{M})$. Its close analogue STC9 exhibited a higher $\mathrm{IC}_{50}(17.2 \pm 1.2 \mu \mathrm{M})$. It was notable that STC8, which lacked a dimethylamino substitution, was devoid of SIRT2 inhibition activity. Overall, 4-dimethylamino- or 4-diethylamino- substitutions in addition to the nitrogen atom of the pyridine ring seemed to be crucial for activity, which was high in accordance with previous TH-3 SAR studies ${ }^{29}$.

The promising SIRT2 inhibition activity of STC4 encouraged us to explore its SAR through further modifications. Compound STC10 with restricted rotation of the carboxamide group was prepared by reacting synthons $\mathbf{3}$ and $\mathbf{1}$ in the presence of triethylamine (Scheme 2). Compound $\mathbf{3}$ was obtained from 4-chloropicolinic acid in two steps as reported previously [34,35]. Of note, STC10 had no activity, indicating the importance of the free rotating $\mathrm{C}-\mathrm{N}$ bond of STC4. To investigate the possible role of the methyl ester group of STC4, we converted it into its hydrazide analogue (compound STC11) by reaction with hydrazine hydrate in ethanol (Scheme 3). The in vitro activity was slightly improved in the hydrazide analogue to reach a single-digit micromolar level $(9.5 \pm 1.2 \mu \mathrm{M})$. The L-histidine nucleus was clearly associated with the superior activity of TH-3 compared with STC4. 


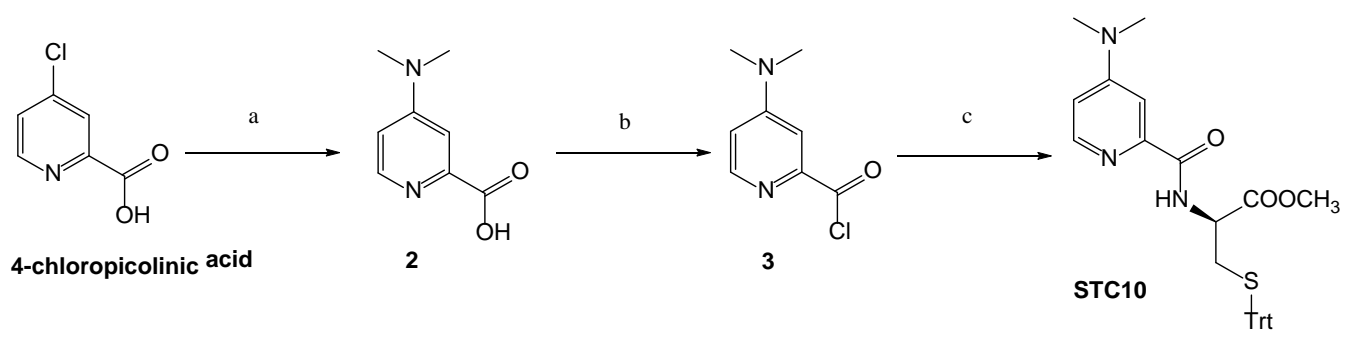

Scheme 2. ${ }^{\text {a }}$ Dimethyl amine aq. sol. $40 \%, 120{ }^{\circ} \mathrm{C}$, sealed tube; ${ }^{\mathrm{b}} \mathrm{SOCl}_{2}$, dimethylformamide, $10 \mathrm{~h}$; c $\mathbf{1}$, triethylamine.
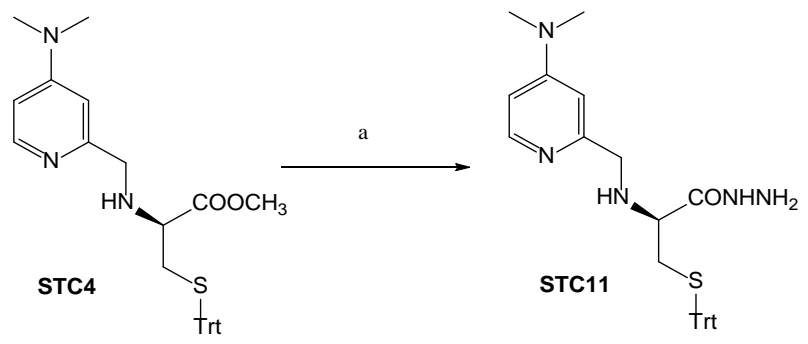

Scheme 3. ${ }^{\text {a }} \mathrm{N}_{2} \mathrm{H}_{4} \cdot \mathrm{H}_{2} \mathrm{O}$, EtOH, room temperature overnight.

Next, the three active compounds (STC4, STC9, and STC11) were utilized for a cell-based assay to explore their potential antiproliferative effect against different cancer cell lines, including MCF7 (breast cancer), HeLa (cervical cancer), and different genotypes of leukemic cells (K562, MT-2, and HL-60) using an MTT assay. The results were compared with the gold standard SirReal2 and TH-3 (Table 2). Compounds STC4 and STC9 showed pronounced and closely similar cytotoxicity against the tested cancer cells in the low micromolar range, whereas HL-60 was exclusively more sensitive to STC4 (IC $50450 \mathrm{nM}$ ). Of note, compounds STC4 and STC9 outperformed cellular SirReal2 activity, but we cannot rule out the presence of other off-target effects. In general, STC11 cellular activity was less than STC4 and STC9. This may be explained by the lower cellular permeability due to the presence of the more polar hydrazide group.

Table 2. $\mathrm{IC}_{50}$ values of selected compounds against multiple cancer cell lines.

\begin{tabular}{cccccc}
\hline \multicolumn{7}{c}{ IC $_{\mathbf{5 0}} \boldsymbol{\mu M}$} \\
\hline MCF-7 & HeLa & K562 & MT-2 & HL-60 \\
\hline SirReal2 & $17.08 \pm 2.15$ & $10.37 \pm 0.94$ & $13.65 \pm 0.44$ & $17.86 \pm 1.52$ & $90.6 \pm 8.77$ \\
STC4 & $3.16 \pm 0.26$ & $1.56 \pm 0.17$ & $2.17 \pm 0.25$ & $3.15 \pm 0.13$ & $0.45 \pm 0.05$ \\
STC9 & $3.32 \pm 0.41$ & $2.72 \pm 0.19$ & $2.53 \pm 0.31$ & $2.55 \pm 0.28$ & $1.19 \pm 0.09$ \\
STC11 & $10.03 \pm 1.12$ & $7.95 \pm 0.81$ & $14.99 \pm 1.17$ & $16.82 \pm 1.04$ & $12.78 \pm 0.95$ \\
TH-3 & $0.71 \pm 0.08$ & $0.37 \pm 0.04$ & $0.30 \pm 0.02$ & $0.17 \pm 0.02$ & $0.28 \pm 0.04$ \\
\hline
\end{tabular}

We then tested DNA cleavage as a possible molecular mechanism for cytotoxicity of the tested compounds using plasmid DNA (pUC19 DNA) witH- and without iron (II), $\mathrm{H}_{2} \mathrm{O}_{2}$, and ascorbic acid complex (Figure 3). The DNA cleavage reaction was carried out by incubating the reaction mixture at $37^{\circ} \mathrm{C}$ for $2 \mathrm{~h}$, and electrophoresis was performed. After electrophoresis, the DNA was stained with ethidium bromide, and the bands were visualized by exposure to ultraviolet radiation and recorded using an electronic camera. STC9 showed the strongest DNA cleavage effect at $1 \mu \mathrm{M}$ concentration, followed by STC11 and STC4, respectively, and it was similar to TH-3. The results indicated that STC4, STC9, and STC11 may generate activated oxygen and cleave DNA at nontoxic concentrations. Furthermore, these compounds may activate oxygen in the cytoplasm. This may explain their high cellular cytotoxic activity owing to a dual effect combining SIRT2 inhibition and DNA cleavage. 


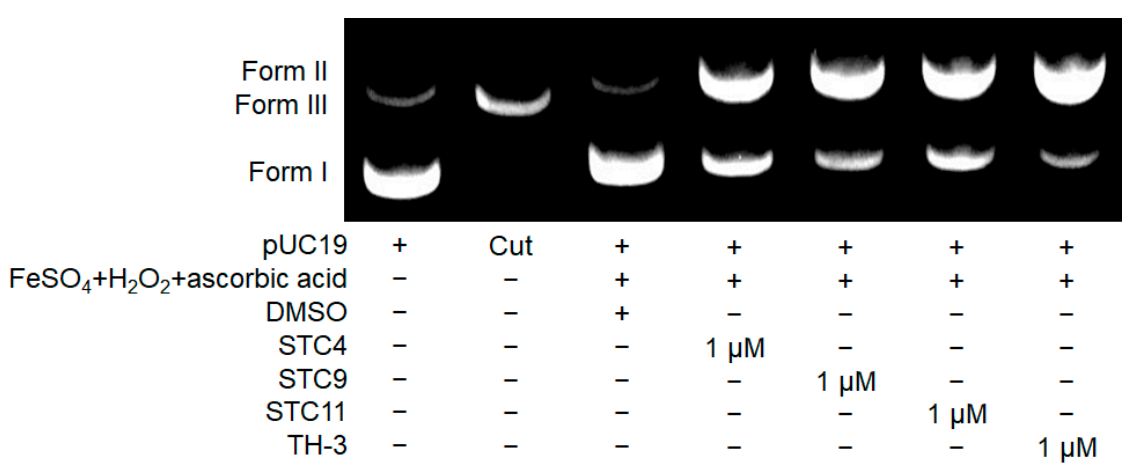

(A)

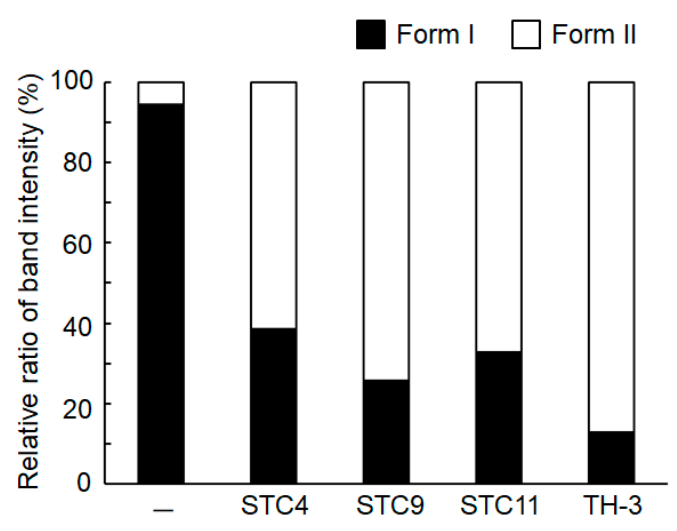

(B)

Figure 3. The inhibitory effects of selected compounds on DNA cleavage in the presence and absence of $\mathrm{FeSO}_{4}, \mathrm{H}_{2} \mathrm{O}_{2}$, and ascorbic acid. (A) Form I (supercoil), form II (single strand break), and form III (double strand break) bands after electrophoresis. The Form I band is the lower and the Form II band is the upper portion. The pUC19 enzyme cut (by EcoR I) generates form III with mid mobility (the second lane from the left). (B) Relative intensity of form I and form II bands.

Next, we performed an in silico molecular docking study to explore the potential binding mode of our compounds on the SIRT2 crystal structure. STC4 is considered as the parent of the less active derivative STC9 and the more active derivative STC11. Subsequently, STC4 was selected for our docking study to elucidate the structural mechanism of SIRT2 inhibition by this new class of compounds.

The co-crystallized ligand SirReal2 was firstly re-docked in its corresponding co-crystal structure (PDB code 4RMG) to test whether the molecular operating environment (MOE) was able to accurately reproduce the correct binding mode of the inhibitor. We kept the conserved structural bridging water molecule (W540) because of its critical importance for the ligand binding affinity to SIRT2 active site as experimentally confirmed in a previous SAR study of potent SIRT2 inhibitors [36]. Figure 4A shows a superimposition of the co-crystallized ligand SirReal2 and its superposed docking conformation, where SirReal2 is perfectly docked into its crystal structure with a root-mean-squared deviation value $0.16 \AA$, and it formed a hydrogen bond with the conserved water molecule (W540) similar to the co-crystallized ligand.

As demonstrated in Figure 4B, the top-scoring position for STC4 fitted into the SIRT2 active site nearly at a similar position of co-crystallized ligand SirReal2. Compared with the more potent SIRT2 inhibitor TH-3 (Figure 4C), it showed that STC4 shared similar interactions and a similar binding orientation, except the binding to the selectivity pocket. STC4 only partially occupied the selectivity pocket, because of its smaller cysteine moiety, compared with the longer histidine moiety of TH-3. This shorter molecular distance of STC4 could explain its moderate affinity to the SIRT2 active site. 
Moreover, the orientation of the dimethylamino group attached to the pyridine moiety of STC4 was not in the correct direction toward the selectivity pocket. On the other hand, extension of the dimethylamino group to diethylamino could cause it to interfere with the amino acid Leu138, which may decrease affinity to the SIRT2 active site, as seen for STC9. Furthermore, binding free energies of the top-ranked docking positions for re-docked SirReal2, TH-3, and STC4 were $-9.97,-8.86$, and $-7.96 \mathrm{kcal} / \mathrm{mol}$, respectively. These binding affinities correlated well with the in vitro SIRT2 inhibition assay (Table 1), where TH-3 inhibited the SIRT2 enzyme more strongly than STC4.

Figure 4D,E illustrated the detailed binding of STC4 to the SIRT2 active site. The ester moiety formed two hydrogen bond interactions with amino acid residue Asn168. These interactions may explain the higher activity of STC11, where the hydrazide moiety in STC11 can form stronger hydrogen bonds with amino acid Asn168 than the ester moiety of STC4. In addition, the trityl moiety formed a $\mathrm{CH}-\pi$ interaction with a key amino acid residue (His178) in the acetyl-lysine channel and blocked the substrate binding site, similar to that described previously for TH-3. These binding interactions may be responsible for the SIRT2 inhibition potency of STC4. However, the absence of the interactions between the dimethylamino group of STC4 and key amino acid residues (Tyr139 and Pro140) in the selectivity pocket may explain the 10-fold decrease in SIRT2 inhibition activity of STC4 compared with that of TH-3. Moreover, the lower affinities of both STC4 and TH-3 compared with SirReal2 partially were due to their inability to form a hydrogen bond with the conserved water molecule (W540). Our in silico analysis elucidated the potential SIRT2 inhibitory mechanism of STC4 mainly through acetyl substrate competition. Despite further structural modifications required to enhance STC4 potency, these results demonstrated that STC4 is a promising SIRT2 inhibitor.

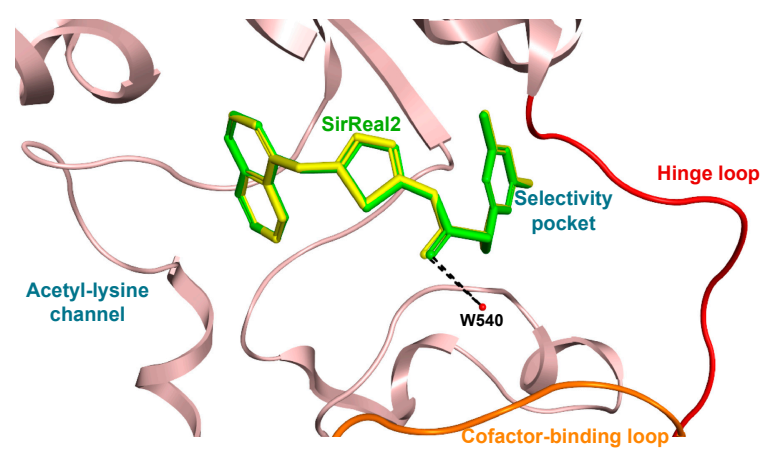

(A)

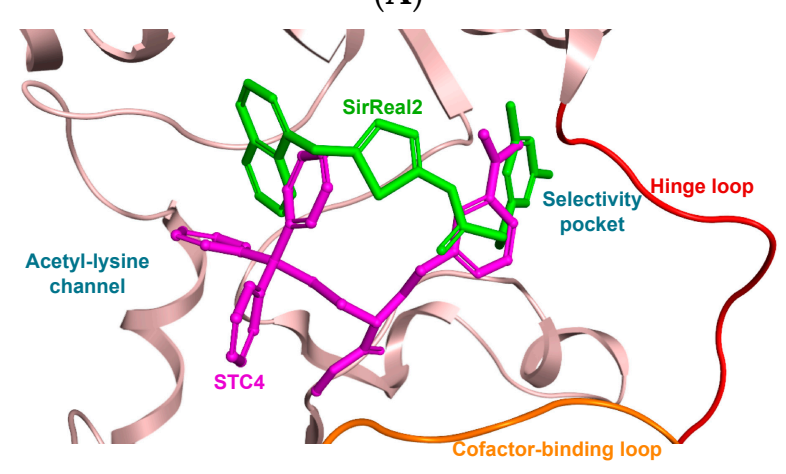

(B)

Figure 4. Cont. 


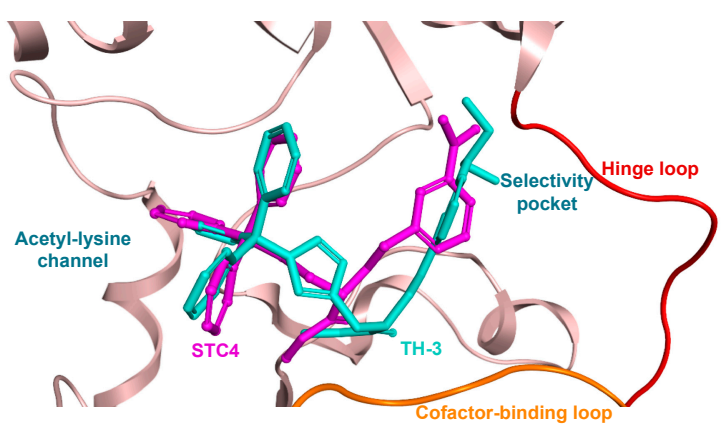

(C)

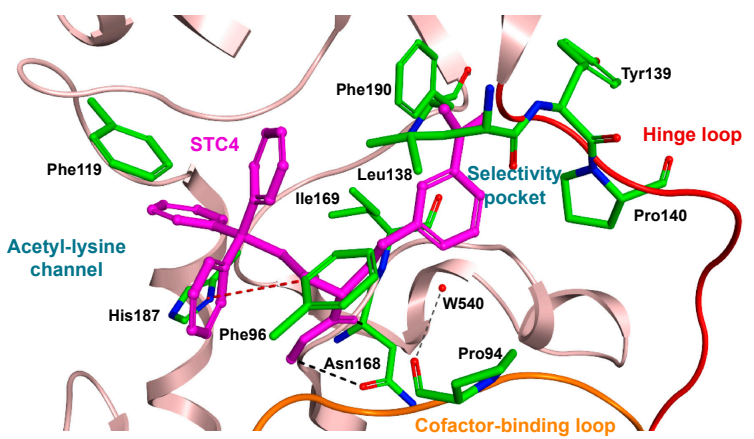

(D)

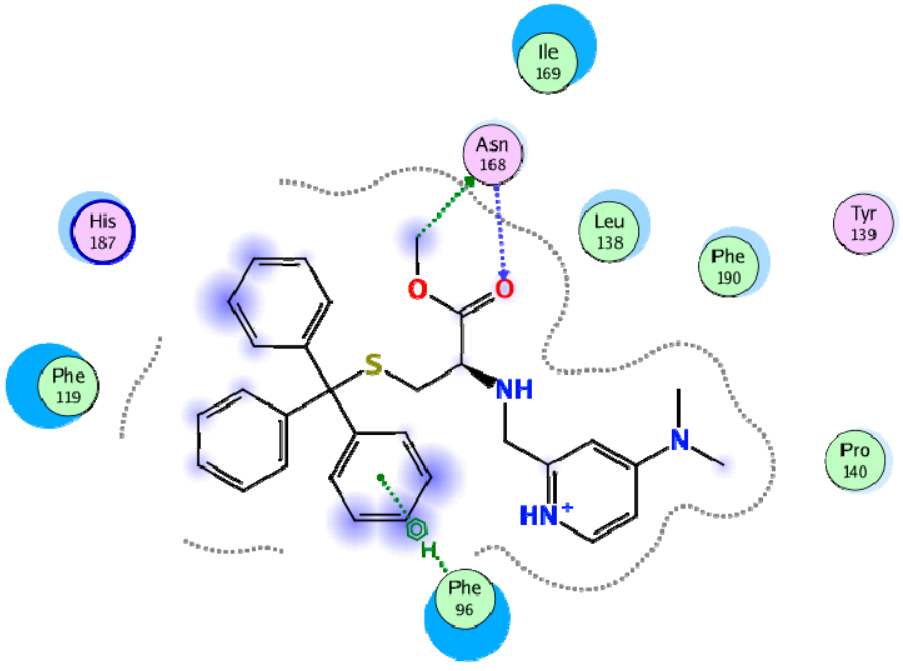

(E)

Figure 4. The top-ranking docked position of STC4 to the SIRT2 active site (PDB code 4RMG) as predicted by MOE 2019.01. (A) Comparison of modeled binding of the co-crystallized ligand SirReal2 (green sticks) and its superposed docking conformation (yellow sticks). (B) Comparison of modeled binding of STC4 (magenta ball-and-stick) and SirReal2 (green sticks). (C) Comparison of modeled binding of STC4 (magenta ball-and-stick) and TH-3 (cyan sticks). (D) Detailed binding of STC4 (magenta ball-and-stick) displaying hydrogen bonds (black dashed line) and $\mathrm{CH}-\pi$ interactions (red dashed line) with the key amino acid residues (green sticks). (E) 2D depiction of STC4 binding interactions with the key amino acid residues.

Finally, we used ADMET predict 9 software to account for the solubility of STC4 and its parent compound. The main parameter $S+S w$ that expresses native water solubility, regardless of $\mathrm{pH}$ value, was -0.982 and -1.956 for STLC and STC4, respectively. The optimal value ranged from -2.406 to -0.982 , which meant that STLC was on the borderline limit; however, STC4 was in the middle 
of the optimal range. To confirm that the STLC solubility profile is enhanced by introducing the aforementioned derivatizations, we compared solubility profiles of STLC and STC4. Herein, we showed the solubility change across a wide range of $\mathrm{pH}$ values (Figure 5). STLC had limited solubility over a wide $\mathrm{pH}$ range of $2-8$. The predicted $\mathrm{pKa}$ values of the acidic carboxyl and basic amino groups appear as dotted red and blue lines, respectively. As for STC4, the solubility was remarkably enhanced over a wider $\mathrm{pH}$ range (0-7). The predicted $\mathrm{pKa}$ values of the three basic amino groups are marked by blue dotted lines. In general, modification of the zwitterion radicals of STLC potentially improved solubility and, hence, the pharmacodynamics features.

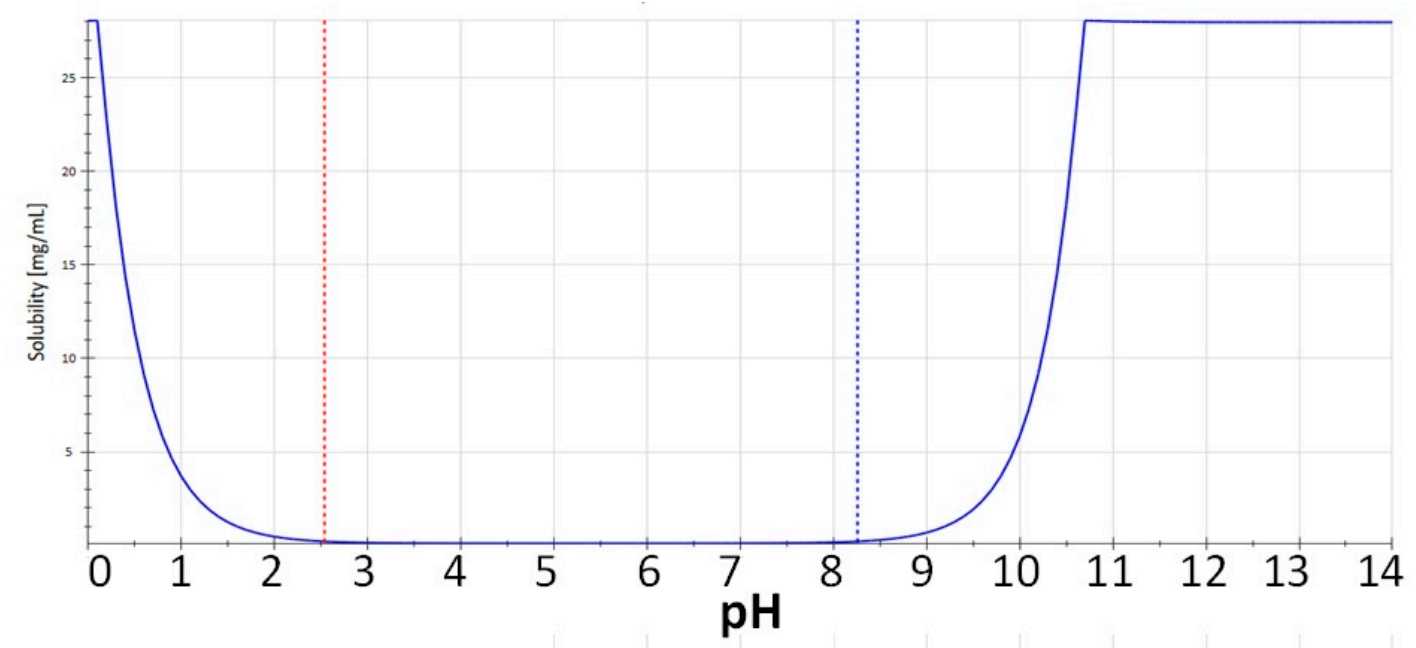

(A)

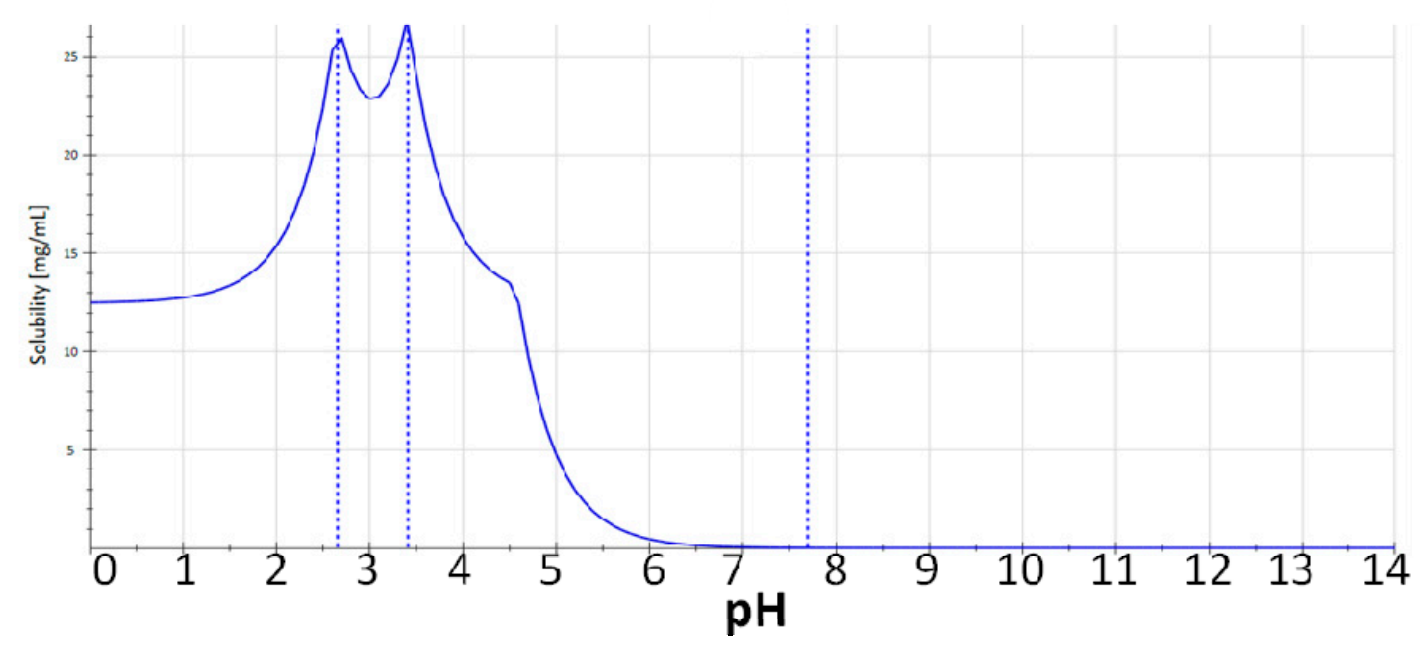

(B)

Figure 5. Solubility profile of free STLC (A) and STC4 (B) at different $\mathrm{pH}$ values.

\section{Materials and Methods}

\subsection{Chemistry}

All reactions were performed in an efficient fume hood. Chemicals were purchased from Sigma-Aldrich (St. Louis, MO, USA), Fluka (Buchs, Switzerland), Kanto Chemical (Tokyo, Japan), Nacalai Tesque (Kyoto, Japan), Tokyo Chemical Industry (Tokyo, Japan), and Wako (Osaka, Japan). Commercially available reagent-grade chemicals were used without further purification. Reaction progress was monitored by thin-layer chromatography (TLC) on precoated plates (Merck, St. Louis, 
MO, USA), TLC 60 F254 silica sheets, and Fuji Silysia Chemical (Kasugai, Japan) TLC Chromatorex $\mathrm{NH}$ silica sheets. Flash column chromatography was carried out on Silica Gel 60N (40-100 mesh, Kanto Chemical, Tokyo, Japan)or NH silica gel Chromatorex (NH, 100-200 mesh, Fuji Silysia Chemical, Kasugai, Japan). Melting points were determined on a melting point apparatus (Yanaco, Kyoto, Japan) and were uncorrected. ${ }^{1} \mathrm{H}$ - and ${ }^{13} \mathrm{C}-\mathrm{NMR}$ spectra were obtained using a Bruker Avance 600 (Billerica, MA, USA) (600 MHz). Chemical shifts were referenced totetramethylsilane. Mass spectra (MS) and high-resolution mass spectra (HRMS) were recorded on a JEOL JMS-DX303HF (Tokyo, Japan) using positive fast atom bombardment $(\mathrm{FAB})$ with 3-nitrobenzyl alcohol as the matrix. Spectral charts are available at the supplementary data file Figures S1-S13.

Synthetic Procedures

S-Trityl-L-Cysteine Methyl Ester Hydrochloride (1). This compound was synthesized and obtained as a white solid in a quantitative yield as described previously by Swarbrick et al. [37]. Spectral data of (1) were in accordance with those reported in literature (Figure S1).

General procedures for reductive alkylation of compound (1) (synthesis of STC1-9) [38] were as follows. Compound (1) $(94.25 \mathrm{mg}, 0.25 \mathrm{mmol})$ and the relevant aldehyde (1.1 equiv.) were dissolved in dry 1,2-DCE and then treated with solid sodium triacetoxyborohydride (74.16 mg, 1.4 equiv.). The reaction mixture was stirred at room temperature, and the reaction progress was monitored by TLC (using NH silica plates; eluent Hex/EA 2:1). Most of the reactions were completed in $3 \mathrm{~h}$. The reaction was then quenched with saturated sodium hydrogen carbonate solution, which was then extracted three times with DCM. The combined organic layers were dried over anhydrous sodium sulfate, and the solvent was removed under reduced pressure. Each product was purified by flash chromatography (NH silica) using the appropriate solvent system.

Methyl N-((6-bromopyridin-2-yl)methyl)-S-trityl-L-cysteinate (STC1). STC1 was prepared using 6-bromopicolinaldehyde; elution with Hex/EA 7:3 afforded 2a as a colorless oil (54.61 $\mathrm{mg}, 40 \%)$. $\left.{ }^{1} \mathrm{H}-\mathrm{NMR}\left(600 \mathrm{MHz}, \mathrm{CDCl}_{3}\right) \delta 2.53(\mathrm{qd}, J=12.6,6.1 \mathrm{~Hz}, 2 \mathrm{H})\right), 3.07(\mathrm{dd}, J=7.0,6.1 \mathrm{~Hz}, 1 \mathrm{H}), 3.65(\mathrm{~s}, 3 \mathrm{H})$, $3.67(\mathrm{~d}, J=15.1 \mathrm{~Hz}, 1 \mathrm{H}), 3.81(\mathrm{~d}, J=15.1 \mathrm{~Hz}, 1 \mathrm{H}), 7.18-7.22(\mathrm{~m}, 3 \mathrm{H}), 7.24-7.28(\mathrm{~m}, 7 \mathrm{H}), 7.33(\mathrm{dd}, J=7.7$, $1.9 \mathrm{~Hz}, 2 \mathrm{H}), 7.39-7.43(\mathrm{~m}, 6 \mathrm{H}), 7.48(\mathrm{t}, J=7.7 \mathrm{~Hz}, 1 \mathrm{H}) .{ }^{13} \mathrm{C}-\mathrm{NMR}\left(150 \mathrm{MHz}, \mathrm{CDCl}_{3}\right) \delta 34.70,52.08,52.58$, $60.19,66.87,120.86,126.32,126.75,127.95,129.62,138.81,141.44,144.57,161.08,173.25$. FAB-MS (m/z) $569(\mathrm{M}+\mathrm{Na})^{+}$; HRFAB-MS calculated for $\mathrm{C}_{29} \mathrm{H}_{27} \mathrm{BrN}_{2} \mathrm{O}_{2} \mathrm{SNa}$ : 569.0874. Found: 569.0878. (Figure S2).

Methyl N-(4-(diethylamino)benzyl)-S-trityl-L-cysteinate (STC2). STC2 was prepared using 4-(diethylamino)benzaldehyde; elution with Hex/EA 7:3 afforded $\mathbf{2 b}$ as a colorless oil $(26.91 \mathrm{mg}, 20 \%$ ). ${ }^{1} \mathrm{H}-\mathrm{NMR}\left(600 \mathrm{MHz}, \mathrm{CDCl}_{3}\right) \delta 1.13(\mathrm{t}, J=7.1 \mathrm{~Hz}, 6 \mathrm{H}), 2.47(\mathrm{dd}, J=6.5,2.6 \mathrm{~Hz}, 2 \mathrm{H}), 3.13(\mathrm{t}, J=6.5 \mathrm{~Hz}$, $1 \mathrm{H}), 3.32(\mathrm{q}, J=7.1 \mathrm{~Hz}, 4 \mathrm{H}), 3.44(\mathrm{~d}, J=12.6 \mathrm{~Hz}, 1 \mathrm{H}), 3.52(\mathrm{~d}, J=12.6 \mathrm{~Hz}, 1 \mathrm{H}), 3.65(\mathrm{~s}, 3 \mathrm{H}), 6.60(\mathrm{~d}, J=8.7$ $\mathrm{Hz}, 2 \mathrm{H}), 7.07(\mathrm{~d}, J=8.7 \mathrm{~Hz}, 2 \mathrm{H}), 7.19-7.22(\mathrm{~m}, 3 \mathrm{H}), 7.24-7.28(\mathrm{~m}, 6 \mathrm{H}), 7.38-7.44(\mathrm{~m}, 6 \mathrm{H}) .{ }^{13} \mathrm{C}-\mathrm{NMR}$ $\left(150 \mathrm{MHz}, \mathrm{CDCl}_{3}\right) \delta 12.59,34.69,44.43,51.28,51.86,59.57,66.67,111.91,126.66,127.90,129.44,129.66$, 144.67, 147.06, 173.91. FAB-MS (m/z) $561(\mathrm{M}+\mathrm{Na})^{+}$; HRFAB-MS calculated for $\mathrm{C}_{34} \mathrm{H}_{38} \mathrm{~N}_{2} \mathrm{O}_{2} \mathrm{SNa}$ : 561.2552. Found: 561.2566. (Figure S3).

Methyl N-(4-(dimethylamino)benzyl)-S-trityl-L-cysteinate (STC3). STC3 was prepared using 4-(dimethylamino)benzaldehyde; elution with Hex/EA 7:3 afforded $2 \mathrm{c}$ as a colorless oil $(31.87 \mathrm{mg}$, 25\%). ${ }^{1} \mathrm{H}-\mathrm{NMR}\left(600 \mathrm{MHz}, \mathrm{CDCl}_{3}\right) \delta 2.47(\mathrm{dd}, J=6.5,3.0 \mathrm{~Hz}, 2 \mathrm{H}), 2.91(\mathrm{~s}, 6 \mathrm{H}), 3.13(\mathrm{t}, J=6.5 \mathrm{~Hz}, 1 \mathrm{H})$, $3.47(\mathrm{~d}, J=12.6 \mathrm{~Hz}, 1 \mathrm{H}), 3.55(\mathrm{~d}, J=12.6 \mathrm{~Hz}, 1 \mathrm{H}), 3.65(\mathrm{~s}, 3 \mathrm{H}), 6.67(\mathrm{~d}, J=8.7 \mathrm{~Hz}, 2 \mathrm{H}), 7.11(\mathrm{~d}, J=8.7$ $\mathrm{Hz}, 2 \mathrm{H}), 7.20$ (ddd, $J=7.3,3.9,1.2 \mathrm{~Hz}, 3 \mathrm{H}), 7.24-7.28(\mathrm{~m}, 6 \mathrm{H}), 7.38-7.42(\mathrm{~m}, 6 \mathrm{H}) .{ }^{13} \mathrm{C}-\mathrm{NMR}(150 \mathrm{MHz}$, $\left.\mathrm{CDCl}_{3}\right) \delta 34.71,40.80,51.27,51.88,59.57,66.69,112.72,126.67,127.91,129.21,129.66,144.68,149.98$, 173.88. FAB-MS (m/z) $533(\mathrm{M}+\mathrm{Na})^{+}$; HRFAB-MS calculated for $\mathrm{C}_{32} \mathrm{H}_{34} \mathrm{~N}_{2} \mathrm{O}_{2} \mathrm{SNa}$ : 533.2239. Found: 533.2557. (Figure S4).

Methyl N-((4-(dimethylamino)pyridin-2-yl)methyl)-S-trityl-L-cysteinate (STC4). STC4 was prepared using 4-(dimethylamino)picolinaldehyde; elution with Hex/EA 1:1 afforded $\mathbf{2 d}$ as a colorless oil (44.71, 35\%). ${ }^{1} \mathrm{H}-\mathrm{NMR}\left(600 \mathrm{MHz}, \mathrm{CDCl}_{3}\right) \delta 2.49-2.55(\mathrm{~m}, 1 \mathrm{H}), 3.14(\mathrm{t}, J=6.7 \mathrm{~Hz}, 1 \mathrm{H}), 2.93(\mathrm{~s}, 6 \mathrm{H}), 3.58(\mathrm{~d}$, 
$J=14.4 \mathrm{~Hz}, 1 \mathrm{H}), 3.64(\mathrm{~s}, 3 \mathrm{H}), 3.75(\mathrm{~d}, J=14.4 \mathrm{~Hz}, 1 \mathrm{H}), 6.35(\mathrm{dd}, J=6.0,2.6 \mathrm{~Hz}, 1 \mathrm{H}), 6.66(\mathrm{~d}, J=2.6$ $\mathrm{Hz}, 1 \mathrm{H}), 7.18-7.20(\mathrm{~m}, 3 \mathrm{H}), 7.24-7.26(\mathrm{~m}, 6 \mathrm{H}), 7.38-7.40(\mathrm{~m}, 6 \mathrm{H}), 8.12(\mathrm{~d}, J=6.0 \mathrm{~Hz}, 1 \mathrm{H}) .{ }^{13} \mathrm{C}-\mathrm{NMR}$ $\left(150 \mathrm{MHz}, \mathrm{CDCl}_{3}\right) \delta 34.91,39.09,51.92,53.46,60.21,66.78,104.71,105.15,126.68,127.89,129.66,144.67$, 149.24, 154.99, 159.14, 173.67. FAB-MS (m/z) $512.5(\mathrm{M}+\mathrm{H})^{+}$; HRFAB-MS calculated for $\mathrm{C}_{31} \mathrm{H}_{33} \mathrm{~N}_{3} \mathrm{O}_{2} \mathrm{~S}$ : 512.2372. Found: 512.2385. (Figure S5).

Methyl N-(2-chloro-4-(dimethylamino)benzyl)-S-trityl-L-cysteinate (STC5). STC5 was prepared using 2-chloro-4-(dimethylamino)benzaldehyde; elution with Hex/EA 7:3 afforded $\mathbf{2 d}$ as a colorless oil (34.10, 25\%). ${ }^{1} \mathrm{H}-\mathrm{NMR}\left(600 \mathrm{MHz}, \mathrm{CDCl}_{3}\right) \delta 2.46-2.52(\mathrm{~m}, 2 \mathrm{H}), 2.91(\mathrm{~s}, 6 \mathrm{H}), 3.08(\mathrm{t}, J=6.5 \mathrm{~Hz}, 1 \mathrm{H}), 3.59-3.67$ $(\mathrm{m}, 2 \mathrm{H}), 3.64(\mathrm{~s}, 3 \mathrm{H}), 6.53(\mathrm{dd}, J=8.5,2.6 \mathrm{~Hz}, 2 \mathrm{H}), 6.65(\mathrm{~d}, J=2.6 \mathrm{~Hz}, 1 \mathrm{H}), 7.10(\mathrm{~d}, J=8.5 \mathrm{~Hz}, 1 \mathrm{H})$, 7.17-7.23 (m, 3H), 7.25-7.28 (m, 6H), 7.40-7.42 (m, 6H). ${ }^{13} \mathrm{C}-\mathrm{NMR}\left(150 \mathrm{MHz}, \mathrm{CDCl}_{3}\right) \delta 31.60,34.69$, $40.45,48.81,51.90,59.71,66.71,110.94,112.98,124.07,126.67,127.91,129.66,130.95,134.65,144.68$, 150.68, 173.63. FAB-MS (m/z) 567.5 (M + Na) ${ }^{+}$; HRFAB-MS calculated for $\mathrm{C}_{32} \mathrm{H}_{33} \mathrm{ClN}_{2} \mathrm{O}_{2} \mathrm{SNa}$ : 567.1849. Found: 567.1859. (Figure S6).

Methyl N-(2-methoxy-4-(dimethylamino)benzyl)-S-trityl-L-cysteinate (STC6). STC6 was prepared using 2-methoxy-4-(dimethylamino)benzaldehyde; elution with Hex/EA 2:1 afforded $\mathbf{2 d}$ as a colorless oil (29.73 mg, 22\%). ${ }^{1} \mathrm{H}-\mathrm{NMR}\left(600 \mathrm{MHz}, \mathrm{CDCl}_{3}\right) \delta 2.51(\mathrm{dd}, J=6.6,1.1 \mathrm{~Hz}, 2 \mathrm{H}), 2.96(\mathrm{~s}, 6 \mathrm{H}), 3.13$ $(\mathrm{t}, J=6.6 \mathrm{~Hz}, 1 \mathrm{H}), 3.55-3.62(\mathrm{~m}, 2 \mathrm{H}), 3.63(\mathrm{~s}, 3 \mathrm{H}), 3.80(\mathrm{~s}, 3 \mathrm{H}), 6.26(\mathrm{dd}, J=8.2,2.4 \mathrm{~Hz}, 1 \mathrm{H}), 6.24$ $(\mathrm{d}, J=2.4 \mathrm{~Hz}, 1 \mathrm{H}), 7.00(\mathrm{~d}, J=8.2 \mathrm{~Hz}, 1 \mathrm{H}), 7.19-7.25(\mathrm{~m}, 3 \mathrm{H}), 7.28-7.31(\mathrm{~m}, 6 \mathrm{H}), 7.43-7.45(\mathrm{~m}, 6 \mathrm{H})$. ${ }^{13} \mathrm{C}-\mathrm{NMR}\left(150 \mathrm{MHz}, \mathrm{CDCl}_{3}\right) \delta 34.68,40.85,46.94,51.79,55.10,59.63,66.61,96.15,104.48,115.89,126.63$, $127.88,127.94,129.63,129.66,129.66,129.67,129.69,129.70,129.70,130.68,144.75,151.57,158.59,173.85$. FAB-MS (m/z) $563.5(\mathrm{M}+\mathrm{Na})^{+}$; HRFAB-MS calculated for $\mathrm{C}_{33} \mathrm{H}_{36} \mathrm{~N}_{2} \mathrm{O}_{3} \mathrm{SNa}$ : 563.2344. Found: 563.2360. (Figure S7).

Methyl N-(quinolin-3-ylmethyl)-S-trityl-L-cysteinate (STC7). STC7 was prepared using quinoline-3-carbaldehyde; elution with Hex/EA 3:1 afforded $2 \mathrm{~g}$ as yellow oil $(25.92 \mathrm{mg}, 20 \%) .{ }^{1} \mathrm{H}-\mathrm{NMR}$ $\left(600 \mathrm{MHz}, \mathrm{CDCl}_{3}\right) \delta 2.54(\mathrm{dd}, J=6.5,2.8 \mathrm{~Hz}, 1 \mathrm{H}), 3.07(\mathrm{t}, J=6.5 \mathrm{~Hz}, 1 \mathrm{H}), 3.67(\mathrm{~s}, 1 \mathrm{H}), 3.72(\mathrm{~d}, J=13.8$ $\mathrm{Hz}, 1 \mathrm{H}), 3.90(\mathrm{~d}, J=13.8 \mathrm{~Hz}, 1 \mathrm{H}), 7.16-7.19(\mathrm{~m}, 3 \mathrm{H}), 7.22-7.26(\mathrm{~m}, 6 \mathrm{H}), 8.81(\mathrm{~s}, 1 \mathrm{H}), 7.38-7.42(\mathrm{~m}, 6 \mathrm{H})$, $7.53(\mathrm{ddd}, J=8.1,6.9,1.2 \mathrm{~Hz}, 1 \mathrm{H}), 7.69(\mathrm{ddd}, J=8.4,6.9,1.2 \mathrm{~Hz}, 1 \mathrm{H}), 7.76(\mathrm{~d}, J=8.1 \mathrm{~Hz}, 1 \mathrm{H}), 8.07(\mathrm{~d}$, $J=1.2 \mathrm{~Hz}, 1 \mathrm{H}), 8.09(\mathrm{~d}, J=8.4 \mathrm{~Hz}, 1 \mathrm{H}) .{ }^{13} \mathrm{C}-\mathrm{NMR}\left(150 \mathrm{MHz}, \mathrm{CDCl}_{3}\right) \delta 34.79,49.27,52.06,59.73,66.90$, $126.69,126.74,126.80,127.65,127.93,129.11,129.22,129.60,132.17,134.73,144.53,147.56,151.47,173.57$. FAB-MS (m/z) $519.4(\mathrm{M}+\mathrm{H})^{+}$; HRFAB-MS calculated for $\mathrm{C}_{33} \mathrm{H}_{31} \mathrm{~N}_{2} \mathrm{O}_{2} \mathrm{~S}: 519.2106$. Found: 519.2118 . (Figure S8).

Methyl N-(pyridin-2-ylmethyl)-S-trityl-L-cysteinate (STC8). STC8 was prepared using picolinaldehyde; elution with Hex/EA 2:1 afforded $2 \mathrm{~g}$ as yellow oil $(37.44 \mathrm{mg}, 32 \%){ }^{1} \mathrm{H}-\mathrm{NMR}\left(600 \mathrm{MHz}, \mathrm{CDCl}_{3}\right) \delta$ 2.44-2.50 (m, 2H), $3.05(\mathrm{t}, J=6.6 \mathrm{~Hz}, 1 \mathrm{H}), 3.57(\mathrm{~d}, J=0.4 \mathrm{~Hz}, 3 \mathrm{H}), 3.62(\mathrm{~d}, J=14.3 \mathrm{~Hz}, 1 \mathrm{H}), 3.73(\mathrm{~d}$, $J=14.3 \mathrm{~Hz}, 1 \mathrm{H}), 7.04-7.06(\mathrm{~m}, 1 \mathrm{H}), 7.11-7.13(\mathrm{~m}, 3 \mathrm{H}), 7.17-7.19(\mathrm{~m}, 6 \mathrm{H}), 7.23(\mathrm{~d}, J=7.6 \mathrm{~Hz}, 1 \mathrm{H})$, 7.33-7.35 (m, 6H), $7.53(\mathrm{td}, J=7.6,1.5 \mathrm{~Hz}, 1 \mathrm{H}), 8.43-8.44(\mathrm{~m}, 1 \mathrm{H}) .{ }^{13} \mathrm{C}-\mathrm{NMR}\left(150 \mathrm{MHz}, \mathrm{CDCl}_{3}\right) \delta 34.68$, $51.98,53.15,60.29,66.80,122.00,122.18,126.71,127.93,129.65,136.45,144.63,149.16,159.14,173.47$. FAB-MS (m/z) $569.1(\mathrm{M}+\mathrm{H})^{+}$; HRFAB-MS calculated for $\mathrm{C}_{29} \mathrm{H}_{29} \mathrm{~N}_{2} \mathrm{O}_{2} \mathrm{~S}: 469.1950$. Found: 469.1956. (Figure S9).

Methyl N-((4-(diethylamino)pyridin-2-yl)methyl)-S-trityl-L-cysteinate (STC9). STC9 was prepared using 4-(diethylamino)picolinaldehyde; elution with Hex/EA 1:1 afforded $\mathbf{2 d}$ as a colorless oil (41.77 $\mathrm{mg}, 31 \%) .{ }^{1} \mathrm{H}-\mathrm{NMR}\left(600 \mathrm{MHz}, \mathrm{CDCl}_{3}\right) \delta 8.08(\mathrm{~d}, J=6.0 \mathrm{~Hz}, 1 \mathrm{H}), 7.38-7.40(\mathrm{~m}, 6 \mathrm{H}), 7.24-7.27(\mathrm{~m}, 6 \mathrm{H})$, $7.18-7.21(\mathrm{~m}, 3 \mathrm{H}), 6.61(\mathrm{~d}, J=2.6 \mathrm{~Hz}, 1 \mathrm{H}), 6.32(\mathrm{dd}, J=6.0,2.6 \mathrm{~Hz}, 1 \mathrm{H}), 3.73(\mathrm{~d}, J=14.3 \mathrm{~Hz}, 1 \mathrm{H}), 3.63$ $(\mathrm{s}, 3 \mathrm{H}), 3.55(\mathrm{~d}, J=14.3 \mathrm{~Hz}, 1 \mathrm{H}), 3.35(\mathrm{dq}, J=14.3,7.1 \mathrm{~Hz}, 1 \mathrm{H}), 3.26(\mathrm{dq}, J=14.3,7.1 \mathrm{~Hz}, 1 \mathrm{H}), 3.13(\mathrm{t}$, $J=6.7 \mathrm{~Hz}, 1 \mathrm{H}), 2.51(\mathrm{dd}, J=6.7,2.6 \mathrm{~Hz}, 1 \mathrm{H}), 1.12(\mathrm{t}, J=7.1 \mathrm{~Hz}, 1 \mathrm{H}) .{ }^{13} \mathrm{C}-\mathrm{NMR}\left(150 \mathrm{MHz}, \mathrm{CDCl}_{3}\right) \delta$ $12.38,34.88,43.72,51.91,53.44,60.13,66.77,104.27,104.80,127.88,129.66,144.66,152.76,159.20,173.66$. FAB-MS (m/z) $540.2(\mathrm{M}+\mathrm{H})^{+}$; HRFAB-MS calculated for $\mathrm{C}_{33} \mathrm{H}_{38} \mathrm{~N}_{3} \mathrm{O}_{2} \mathrm{~S}: 540.2685$. Found: 540.2720 . (Figure S10). 
3-(Dimethylamino)picolinic acid (2). A solution of 4-chloropicolinic acid (200 mg, $1.25 \mathrm{mmol}$ ) in aqueous dimethylamine $(40 \%, 3.1 \mathrm{~mL})$ was stirred at $150{ }^{\circ} \mathrm{C}$ for $2 \mathrm{~h}$ in a sealed tube. The mixture was concentrated in vacuo, dissolved in EtOAc $(20 \mathrm{~mL})$, and washed with saturated aqueous $\mathrm{NaHCO}_{3}$ (20 mL). The organic phase was dried over $\mathrm{Na}_{2} \mathrm{SO}_{4}$ and evaporated in vacuo to afford $2(190 \mathrm{mg}, 90 \%)$ as a white solid [34]. ${ }^{1} \mathrm{H}-\mathrm{NMR}(600 \mathrm{MHz}, \mathrm{DMSO}) \delta 3.08$ (s, 6H), 6.77 (brs, 1H), 7.29 (brs, 1H), 8.09 (brs, 1H). m.p. $>300^{\circ} \mathrm{C}$. FAB-MS (m/z) $167.0(\mathrm{M}+\mathrm{H})^{+}$. (Figure S11).

3-(Dimethylamino)picolinoyl chloride (3). Compound 2 (190 mg, $1.1 \mathrm{mmol}$ ) was refluxed with $5 \mathrm{~mL}$ of $\mathrm{SOCl}_{2}$ in the presence of a catalytic amount of dimethylformamide for $10 \mathrm{~h}$. The mixture was concentrated and dried to afford a yellow solid (3) in a quantitative yield, which was used without further purification [31].

Methyl N-(4-(dimethylamino)picolinoyl)-S-trityl-L-cysteinate (STC10) [35]. A batch of compound (1) $(94.25 \mathrm{mg}, 0.25 \mathrm{mmol})$ and TEA (1.5 equiv.) were mixed in DCM at $0{ }^{\circ} \mathrm{C}$. Then, the freshly synthesized acyl chloride (3) $(46.15 \mathrm{mg}, 0.25 \mathrm{mmol})$ in DCM was added dropwise. The mixture was stirred overnight at room temperature then analyzed by TLC. Upon reaction completion, the crude mixture was washed with water, and the organic layer was dried over anhydrous sodium sulfate. The residue was applied to an NH silica column chromatography to obtain a pure product using Hex/EA 1:1 eluent to afford STC10 as a white solid (35.45 mg, 27\%). ${ }^{1} \mathrm{H}-\mathrm{NMR}\left(600 \mathrm{MHz}, \mathrm{CDCl}_{3}\right) \delta 2.68-2.76(\mathrm{~m}, 2 \mathrm{H}), 3.05(\mathrm{~s}, 6 \mathrm{H})$, $3.71(\mathrm{~s}, 3 \mathrm{H}), 4.69-4.72(\mathrm{~m}, 1 \mathrm{H}), 6.56(\mathrm{dd}, J=8.1,2.8 \mathrm{~Hz}, 1 \mathrm{H}), 7.17-7.20(\mathrm{~m}, 3 \mathrm{H}), 7.23-7.26(\mathrm{~m}, 6 \mathrm{H})$, $7.39-7.41(\mathrm{~m}, 6 \mathrm{H}), 8.20(\mathrm{~d}, J=2.8 \mathrm{~Hz}, 1 \mathrm{H}), 8.63(\mathrm{~d}, J=8.1 \mathrm{~Hz}, 1 \mathrm{H}) .{ }^{13} \mathrm{C}-\mathrm{NMR}\left(150 \mathrm{MHz}, \mathrm{CDCl}_{3}\right) \delta$ $34.19,39.27,51.44,52.53,66.99,105.36,108.29,126.79,127.96,129.62,144.43,148.49,149.46,155.20$, 165.05, 170.84. m.p. $54-55^{\circ} \mathrm{C}$. FAB-MS (m/z) $526.2(\mathrm{M}+\mathrm{H})^{+}$; HRFAB-MS calculated for $\mathrm{C}_{31} \mathrm{H}_{32} \mathrm{~N}_{3} \mathrm{O}_{3} \mathrm{~S}$ : 526.2164. Found: 526.2168. (Figure S12).

(S)-2-((4-(dimethylamino)pyridin-2-yl)methyl)amino)-3-(tritylthio)propanehydrazide (STC11). STC11 was prepared by reacting STC4 $(30.20 \mathrm{mg}, 0.05 \mathrm{mmol})$ with hydrazine hydrate in EtOH, in accordance with previously reported procedures [39]. A white solid product was obtained in a quantitative yield. ${ }^{1} \mathrm{H}-\mathrm{NMR}\left(600 \mathrm{MHz} \mathrm{CDCl}_{3}\right) \delta 2.23(\mathrm{brs}, 2 \mathrm{H}), 2.56(\mathrm{dd}, J=12.8,8.8 \mathrm{~Hz}, 1 \mathrm{H}), 2.70$ $(\mathrm{dd}, J=12.8,4.3 \mathrm{~Hz}, 1 \mathrm{H}), 2.70(\mathrm{dd}, J=12.8,4.3 \mathrm{~Hz}, 1 \mathrm{H}), 2.88(\mathrm{dd}, J=8.8,4.3 \mathrm{~Hz}, 1 \mathrm{H}), 2.97(\mathrm{~s}, 6 \mathrm{H})$, $3.53-3.59(\mathrm{~m}, 2 \mathrm{H}), 6.38(\mathrm{dd}, J=6.0,2.6 \mathrm{~Hz}, 1 \mathrm{H}), 6.42(\mathrm{~d}, J=2.6 \mathrm{~Hz}, 1 \mathrm{H}), 7.18-7.21(\mathrm{~m}, 3 \mathrm{H}), 7.25-7.28$ $(\mathrm{m}, 6 \mathrm{H}), 7.40-7.42(\mathrm{~m}, 6 \mathrm{H}), 8.16(\mathrm{~d}, J=6.0 \mathrm{~Hz}, 1 \mathrm{H}), 8.65(\mathrm{~s}, 1 \mathrm{H}) .{ }^{13} \mathrm{C}-\mathrm{NMR}\left(150 \mathrm{MHz}, \mathrm{CDCl}_{3}\right) \delta 35.06$, $39.17,53.56,60.28,66.99,104.79,105.29,126.79,127.98,129.65,144.56,148.87,155.06,158.38,172.61$. m.p. $162-164{ }^{\circ} \mathrm{C}$. FAB-MS (m/z) $534.3(\mathrm{M}+\mathrm{Na})^{+}$; HRFAB-MS calculated for $\mathrm{C}_{30} \mathrm{H}_{33} \mathrm{~N}_{5} \mathrm{OSNa}$ : 534.2304. Found: 534.2301. (Figure S13).

\subsection{Biological Assays}

\subsubsection{In Vitro Inhibitory Activities against SIRT2}

Deacetylase activities of SIRT2 were measured with an electrophoretic mobility shift assay [24,40]. For the electrophoretic mobility shift assay to measure SIRT2 activity, recombinant SIRT2 proteins were incubated with a carboxyfluorescein (FAM)-labeled fluorescent peptide (FAM-RHKK(Ac)LM) and $1 \mathrm{mM}$ NAD in $50 \mu \mathrm{L}$ assay buffer $(25 \mathrm{mM}$ Tris- $\mathrm{HCl}$, (pH 9.0), $137 \mathrm{mM} \mathrm{NaCl}, 2.7 \mathrm{mM} \mathrm{KCl}, 1 \mathrm{mM} \mathrm{MgCl}$, $0.1 \mathrm{mg} / \mathrm{mL}$ bovine serum albumin) in 384 -well plates. After $60 \mathrm{~min}$ at $37^{\circ} \mathrm{C}$, the reaction was stopped by adding nicotinamide (final concentration $10 \mathrm{mM}$ ) in $50 \mu \mathrm{L}$ stop buffer (100 mM HEPES (pH 7.5), $10 \mathrm{mM}$ EDTA, $0.25 \%$ CR-3). The samples were analyzed using a LabChip EZ Reader II (PerkinElmer, Waltham, MA, USA). Percent conversion was defined as $100 \times \mathrm{P} /(\mathrm{P}+\mathrm{S})$, where $\mathrm{P}$ and $\mathrm{S}$ are peak heights of the product and peptide substrate, respectively. The $\mathrm{IC}_{50}$ values were determined as means with standard deviation calculated from at least three independent dose-response curves using Origin software (OriginLab, Northampton, MA, USA). 


\subsubsection{Cell Culture and Drug Treatment}

HeLa human cervical carcinoma cell lines were incubated in Dulbecco's modified Eagle's medium. MCF-7 human breast cancer, leukemic (K562, HL-60, MT-2, and Jurkat), and normal blood (PBMC) (Precision Bioservices, Frederic, MD, USA) cells were incubated in RPMI1640 medium. All media (Wako, Osaka, Japan) were supplemented with 10\% fetal bovine serum (Sigma-Aldrich, St. Louis, MO, USA) and $89 \mu \mathrm{g} / \mathrm{mL}$ streptomycin (Meiji Seika, Tokyo, Japan) at $37^{\circ} \mathrm{C}$ in a humidified atmosphere of 95\% air and 5\% $\mathrm{CO}_{2}$. Exponentially growing cells were cultured in 24-well and 96-well plates (Iwaki brand Asahi Glass, Tokyo, Japan) at $2 \times 10^{4}$ cells $/ \mathrm{mL}$ and $1 \times 10^{6}$ cells $/ \mathrm{mL}$, respectively, for $96 \mathrm{~h}$ before the addition of drugs (optimum cell number for cytotoxicity assays was determined in preliminary experiments). Stock solutions of compounds in concentrations between $0.01-10 \mathrm{mM}$ were prepared in dimethyl sulfoxide (DMSO; Wako, Osaka, Japan) and further dilution was made with fresh culture medium. The concentration of DMSO in the final culture medium was $1 \%$, which had no effect on cell viability [41].

\subsubsection{MTT Assay}

The level of cellular MTT (Dojindo, Kumamoto, Japan) reduction was quantified as described previously [42,43] After $24 \mathrm{~h}$ of preincubation at $37^{\circ} \mathrm{C}$, cells were exposed to various concentrations $(0.1-100 \mu \mathrm{M})$ of the tested compounds and SirReal2 (positive control) for $96 \mathrm{~h}$. At the end of this period, cells were stained with MTT solution and incubated for an additional $4 \mathrm{~h}$ at $37^{\circ} \mathrm{C}$. After the medium was removed, the formazan crystals were solubilized by addition of $100 \mu \mathrm{L}$ DMSO to each well, and absorbance was determined using an Infinitive M1000 plate reader (Tecan, Mannedorf, Switzerland) at a wavelength of $550 \mathrm{~nm}$ with background subtraction at $630 \mathrm{~nm}$. Every concentration was repeated in three wells, and $\mathrm{IC}_{50}$ values were calculated from MTT results and defined as the drug concentrations that reduced absorbance to $50 \%$ of the control values.

\subsubsection{DNA Cleavage}

The DNA cleavage assays were performed as described previously [32,44,45]. Intensity of the bands was quantitated using ImageJ software (NIH, Bethesda, MD, USA).

\subsection{Molecular Docking}

Sirt2 X-ray structure Sirt2-SirReal2-NAD (PDB code 4RMG) [30] was used in the present study. The protein structure was prepared using the structure preparation module in MOE (Version 2019.01, Chemical Computing Group Inc., Montreal, QC, Canada). Water molecules and ligand atoms, except the zinc ion and the conserved water molecule bridging the interaction between Pro94 and the carbonyl group of SirReal2, were removed from the structure. Docking studies were performed using the rigid-receptor method [46,47]. The co-crystallized ligand (SirReal2) was defined as the center of the binding site. Three hundred docking positions were generated for each ligand. All other options were left at their default values [48]. The co-crystallized ligand was also docked with other compounds for validation of the docking method. The binding free energy $(\Delta \mathrm{G})$ in $\mathrm{kcal} / \mathrm{mol}$ of the re-docked SirReal2 and the inhibitors of this study were calculated using the top-scoring docking positions. The generated docking positions were visualized using MOE [49].

\section{Conclusions}

In this study, we found a new target for STLC-derived compounds distinct from their well-known mitotic kinesin Eg5 inhibition. The introduced derivatizations not only conferred STLC with SIRT2 inhibitory effect but also addressed its pharmacokinetic issue and enhanced its water solubility. Three compounds showed pronounced SIRT2 inhibition and antiproliferative effects against different cancer cell lines, making them promising candidates for further optimization. 
Supplementary Materials: The following are available online at http://www.mdpi.com/1420-3049/24/18/3295/s1, Figure S1: ${ }^{1} \mathrm{H}-\mathrm{NMR}$ of compound 1; Figure S2: ${ }^{1} \mathrm{H}$ and ${ }^{13} \mathrm{C}$ NMR of STC1; Figure S3: ${ }^{1} \mathrm{H}-$ and ${ }^{13} \mathrm{C}-\mathrm{NMR}$ of STC2; Figure S4: ${ }^{1} \mathrm{H}$ - and ${ }^{13} \mathrm{C}-\mathrm{NMR}$ of STC3; Figure S5: ${ }^{1} \mathrm{H}$ - and ${ }^{13} \mathrm{C}-\mathrm{NMR}$ of STC4; Figure S6: ${ }^{1} \mathrm{H}$ - and ${ }^{13} \mathrm{C}-\mathrm{NMR}$ of STC5; Figure S7: ${ }^{1} \mathrm{H}$ - and ${ }^{13} \mathrm{C}-\mathrm{NMR}$ of STC6; Figure S8: ${ }^{1} \mathrm{H}$ - and ${ }^{13} \mathrm{C}-\mathrm{NMR}$ of STC7; Figure S9: ${ }^{1} \mathrm{H}-$ and ${ }^{13} \mathrm{C}-\mathrm{NMR}$ of STC8; Figure S10: ${ }^{1} \mathrm{H}$ - and ${ }^{13} \mathrm{C}-\mathrm{NMR}$ of STC9; Figure S11: ${ }^{1} \mathrm{H}-\mathrm{NMR}$ of compound 2; Figure S12: ${ }^{1} \mathrm{H}$ - and ${ }^{13} \mathrm{C}-\mathrm{NMR}$ of STC10; Figure S13: ${ }^{1} \mathrm{H}$ - and ${ }^{13} \mathrm{C}-\mathrm{NMR}$ of STC11.

Author Contributions: M.O.R., H.I.C., and T.F.S.A. designed the research; M.O.R. and T.F.S.A. carried out the synthetic work, docking studies, and in silico pharmacokinetic study. H.I.C. and D.E.E. were responsible for the cell-based biological assay. R.K. performed cell culture. A.N., A.I. and M.Y. performed the in vitro assay. Y.O. and H.T. discussed and edited the manuscript. M.O.R., M.O. and M.F. mainly wrote the manuscript. M.F. and M.O. were responsible for the correspondence of the manuscript. All authors discussed, edited and approved the final version.

Funding: We are grateful to the Screening Committee of Anticancer Drugs supported by a Grant-in-Aid for Scientific Research on Innovative Areas, Scientific Support Programs for Cancer Research (No. 221S0001), from The Ministry of Education, Culture, Sports, Science and Technology, Japan (MEXT), for assistance with the evaluation of compounds. This work was supported by a Grant for Joint Research Project with Science Farm Ltd. The study was also supported in part by a Grant-in-Aid for Challenging Exploratory Research to M.O. (24659048).

Acknowledgments: MCF7 cells were provided by the RIKEN BRC through the National Bio-Resource Project of the MEXT/AMED, Japan.

Conflicts of Interest: The authors report no conflict of interest.

\section{References}

1. DeBonis, S.; Skoufias, D.A.; Lebeau, L.; Lopez, R.; Robin, G.; Margolis, R.L.; Wade, R.H.; Kozielski, F. In Vitro Screening for Inhibitors of the Human Mitotic Kinesin Eg5 with Antimitotic and Antitumor Activities. Mol. Cancer Ther. 2004, 3, 1079-1090. [PubMed]

2. Skoufias, D.A.; DeBonis, S.; Saoudi, Y.; Lebeau, L.; Crevel, I.; Cross, R.; Wade, R.H.; Hackney, D.; Kozielski, F. $S$-Trityl-L-Cysteine Is a Reversible, Tight Binding Inhibitor of the Human Kinesin Eg5 That Specifically Blocks Mitotic Progression. J. Biol. Chem. 2006, 281, 17559-17569. [CrossRef] [PubMed]

3. Shimizu, M.; Ishii, H.; Ogo, N.; Unno, Y.; Matsuno, K.; Sawada, J.; Akiyama, Y.; Asai, A. S-trityl- L -cysteine derivative induces caspase-independent cell death in K562 human chronic myeloid leukemia cell line. Cancer Lett. 2010, 298, 99-106. [CrossRef] [PubMed]

4. Ogo, N.; Oishi, S.; Matsuno, K.; Sawada, J.; Fujii, N.; Asai, A. Synthesis and Biological Evaluation of L-Cysteine Derivatives as Mitotic Kinesin Eg5 Inhibitors. Bioorganic Med. Chem. Lett. 2007, 17, 3921-3924. [CrossRef] [PubMed]

5. Boyd, M.R.; Paull, K.D. Some Practical Considerations and Applications of the National Cancer Institute in Vitro Anticancer Drug Discovery Screen. Drug Dev. Res. 1995, 34, 91-109. [CrossRef]

6. Purcell, J.W.; Davis, J.; Reddy, M.; Martin, S.; Samayoa, K.; Vo, H.; Thomsen, K.; Bean, P.; Kuo, W.L.; Ziyad, S.; et al. Activity of the Kinesin Spindle Protein Inhibitor Ispinesib (SB-715992) in Models of Breast Cancer. Clin. Cancer Res. 2010, 16, 566-576. [CrossRef]

7. El-Nassan, H.B. Advances in the Discovery of Kinesin Spindle Protein (Eg5) Inhibitors as Antitumor Agents. Eur. J. Med. Chem. 2013, 62, 614-631. [CrossRef]

8. Rath, O.; Kozielski, F. Kinesins and Cancer. Nat. Rev. Cancer 2012, 12, 527-539. [CrossRef]

9. Perez-Melero, C. KSP Inhibitors as Antimitotic Agents. Curr. Top. Med. Chem. 2014, 14, 2286-2311. [CrossRef]

10. Rodriguez, D.; Ramesh, C.; Henson, L.H.; Wilmeth, L.; Bryant, B.K.; Kadavakollu, S.; Hirsch, R.; Montoya, J.; Howell, P.R.; George, J.M.; et al. Synthesis and Characterization of Tritylthioethanamine Derivatives with Potent KSP Inhibitory Activity. Bioorganic Med. Chem. 2011, 19, 5446-5453. [CrossRef]

11. DeBonis, S.; Skoufias, D.A.; Indorato, R.L.; Liger, F.; Marquet, B.; Laggner, C.; Joseph, B.; Kozielski, F. Structure-Activity Relationship of S-Trityl-L-Cysteine Analogues as Inhibitors of the Human Mitotic Kinesin Eg5. J. Med. Chem. 2008, 51, 1115-1125. [CrossRef] [PubMed]

12. Kaan, H.Y.K.; Weiss, J.; Menger, D.; Ulaganathan, V.; Tkocz, K.; Laggner, C.; Popowycz, F.; Joseph, B.; Kozielski, F. Structure-Activity Relationship and Multidrug Resistance Study of New $S$-Trityl- $l$-Cysteine Derivatives As Inhibitors of Eg5. J. Med. Chem. 2011, 54, 1576-1586. [CrossRef] [PubMed] 
13. Myers, S.M.; Collins, I. Recent Findings and Future Directions for Interpolar Mitotic Kinesin Inhibitors in Cancer Therapy. Future Med. Chem. 2016, 8, 463-489. [CrossRef] [PubMed]

14. Kim, E.D.; Buckley, R.; Learman, S.; Richard, J.; Parke, C.; Worthylake, D.K.; Wojcik, E.J.; Walker, R.A.; Kim, S. Allosteric Drug Discrimination Is Coupled to Mechanochemical Changes in the Kinesin-5 Motor Core. J. Biol. Chem. 2010, 285, 18650-18661. [CrossRef] [PubMed]

15. Abualhasan, M.N.; Good, J.A.D.; Wittayanarakul, K.; Anthony, N.G.; Berretta, G.; Rath, O.; Kozielski, F.; Sutcliffe, O.B.; Mackay, S.P. Doing the Methylene Shuffle - Further Insights into the Inhibition of Mitotic Kinesin Eg5 with S-Trityl- L-Cysteine. Eur. J. Med. Chem. 2012, 54, 483-498. [CrossRef] [PubMed]

16. Zhou, Z.; Ma, T.; Zhu, Q.; Xu, Y.; Zha, X. Recent Advances in Inhibitors of Sirtuin1/2: An Update and Perspective. Future Med. Chem. 2018, 10, 907-934. [CrossRef] [PubMed]

17. Schiedel, M.; Robaa, D.; Rumpf, T.; Sippl, W.; Jung, M. The Current State of NAD + -Dependent Histone Deacetylases (Sirtuins) as Novel Therapeutic Targets. Med. Res. Rev. 2018, 38, 147-200. [CrossRef]

18. H Beumer, J.; Tawbi, H. Role of Histone Deacetylases and Their Inhibitors in Cancer Biology and Treatment. Curr. Clin. Pharmacol. 2010, 5, 196-208. [CrossRef]

19. North, B.J.; Marshall, B.L.; Borra, M.T.; Denu, J.M.; Verdin, E. The human Sir2 ortholog, SIRT2, is an NAD+-dependent tubulin deacetylase. Mol. Cell 2003, 11,437-444, PMID: 12620231. [CrossRef]

20. Ito, A.; Shimazu, T.; Maeda, S.; Shah, A.A.; Tsunoda, T.; Iemura, S.; Natsume, T.; Suzuki, T.; Motohashi, H.; Yamamoto, M.; et al. The subcellular localization and activity of cortactin is regulated by acetylation and interaction with Keap1. Sci. Signal. 2015, 24, PMID: 26602019. [CrossRef]

21. Deng, A.; Ning, Q.; Zhou, L.; Liang, Y. SIRT2 Is an Unfavorable Prognostic Biomarker in Patients with Acute Myeloid Leukemia. Sci. Rep. 2016, 6, 27694. [CrossRef] [PubMed]

22. Jing, H.; Hu, J.; He, B.; Negrón Abril, Y.L.; Stupinski, J.; Weiser, K.; Carbonaro, M.; Chiang, Y.-L.; Southard, T.; Giannakakou, P.; et al. A SIRT2-Selective Inhibitor Promotes c-Myc Oncoprotein Degradation and Exhibits Broad Anticancer Activity. Cancer Cell 2016, 29, 297-310. [CrossRef] [PubMed]

23. Carafa, V.; Rotili, D.; Forgione, M.; Cuomo, F.; Serretiello, E.; Hailu, G.S.; Jarho, E.; Lahtela-Kakkonen, M.; Mai, A.; Altucci, L. Sirtuin Functions and Modulation: From Chemistry to the Clinic. Clin. Epigenetics 2016, 8, 61. [CrossRef]

24. Shah, A.A.; Ito, A.; Nakata, A.; Yoshida, M. Identification of a Selective SIRT2 Inhibitor and Its Anti-Breast Cancer Activity. Biol. Pharm. Bull. 2016, 39, 1739-1742. [CrossRef] [PubMed]

25. Sunami, Y.; Araki, M.; Hironaka, Y.; Morishita, S.; Kobayashi, M.; Liew, E.L.; Edahiro, Y.; Tsutsui, M.; Ohsaka, A.; Komatsu, N. Inhibition of the NAD-Dependent Protein Deacetylase SIRT2 Induces Granulocytic Differentiation in Human Leukemia Cells. PLoS ONE 2013, 8. [CrossRef]

26. Kozako, T.; Mellini, P.; Ohsugi, T.; Aikawa, A.; Uchida, Y.; Honda, S.; Suzuki, T. Novel Small Molecule SIRT2 Inhibitors Induce Cell Death in Leukemic Cell Lines. Bmc Cancer 2018, 18, 791. [CrossRef] [PubMed]

27. Moniot, S.; Forgione, M.; Lucidi, A.; Hailu, G.S.; Nebbioso, A.; Carafa, V.; Baratta, F.; Altucci, L.; Giacché, N.; Passeri, D.; et al. Development of 1,2,4-Oxadiazoles as Potent and Selective Inhibitors of the Human Deacetylase Sirtuin 2: Structure-Activity Relationship, X-Ray Crystal Structure, and Anticancer Activity. J. Med. Chem. 2017, 60, 2344-2360. [CrossRef]

28. Li, Y.; Matsumori, H.; Nakayama, Y.; Osaki, M.; Kojima, H.; Kurimasa, A.; Ito, H.; Mori, S.; Katoh, M.; Oshimura, M.; et al. SIRT2 Down-Regulation in HeLa Can Induce P53 Accumulation via P38 MAPK Activation-Dependent P300 Decrease, Eventually Leading to Apoptosis. Genes Cells 2011, 16, $34-45$. [CrossRef]

29. Ali, T.F.S.; Ciftci, H.I.; Radwan, M.O.; Koga, R.; Ohsugi, T.; Okiyama, Y.; Honma, T.; Nakata, A.; Ito, A.; Yoshida, M.; et al. New SIRT2 Inhibitors: Histidine-Based Bleomycin Spin-Off. Bioorganic Med. Chem. 2019, 27, 1767-1775. [CrossRef]

30. Rumpf, T.; Schiedel, M.; Karaman, B.; Roessler, C.; North, B.J.; Lehotzky, A.; Oláh, J.; Ladwein, K.I.; Schmidtkunz, K.; Gajer, M.; et al. Selective Sirt2 Inhibition by Ligand-Induced Rearrangement of the Active Site. Nat. Commun. 2015, 6, 6263. [CrossRef]

31. Radwan, M.O.; Sonoda, S.; Ejima, T.; Tanaka, A.; Koga, R.; Okamoto, Y.; Fujita, M.; Otsuka, M. Zinc-Mediated Binding of a Low-Molecular-Weight Stabilizer of the Host Anti-Viral Factor Apolipoprotein B MRNA-Editing Enzyme, Catalytic Polypeptide-like 3G. Bioorganic Med. Chem. 2016, 24, 4398-4405. [CrossRef] [PubMed] 
32. Ali, T.F.S.; Iwamaru, K.; Ciftci, H.I.; Koga, R.; Matsumoto, M.; Oba, Y.; Kurosaki, H.; Fujita, M.; Okamoto, Y.; Umezawa, K.; et al. Novel Metal Chelating Molecules with Anticancer Activity. Striking Effect of the Imidazole Substitution of the Histidine-Pyridine-Histidine System. Bioorganic Med. Chem. 2015, 23, 5476-5482. [CrossRef] [PubMed]

33. Radwan, M.O.; Koga, R.; Hida, T.; Ejima, T.; Kanemaru, Y.; Tateishi, H.; Okamoto, Y.; Inoue, J.; Fujita, M.; Otsuka, M. Minimum Structural Requirements for Inhibitors of the Zinc Finger Protein TRAF6. Bioorganic Med. Chem. Lett. 2019, 29, 2162-2167. [CrossRef] [PubMed]

34. Yeoh, K.K.; Chan, M.C.; Thalhammer, A.; Demetriades, M.; Chowdhury, R.; Tian, Y.-M.; Stolze, I.; McNeill, L.A.; Lee, M.K.; Woon, E.C.Y.; et al. Dual-Action Inhibitors of HIF Prolyl Hydroxylases That Induce Binding of a Second Iron Ion. Org. Biomol. Chem. 2013, 11, 732-745. [CrossRef] [PubMed]

35. Radwan, M.O.; Ismail, M.A.H.; El-Mekkawy, S.; Ismail, N.S.M.; Hanna, A.G. Synthesis and Biological Activity of New $18 \beta$-Glycyrrhetinic Acid Derivatives. Arab. J. Chem. 2016, 9, 390-399. [CrossRef]

36. Schiedel, M.; Rumpf, T.; Karaman, B.; Lehotzky, A.; Oláh, J.; Gerhardt, S.; Ovádi, J.; Sippl, W.; Einsle, O.; Jung, M. Aminothiazoles as Potent and Selective Sirt2 Inhibitors: A Structure- Activity Relationship Study. J. Med. Chem. 2016, 59, 1599-1612. [CrossRef] [PubMed]

37. Swarbrick, J.D.; Ung, P.; Chhabra, S.; Graham, B. An Iminodiacetic Acid Based Lanthanide Binding Tag for Paramagnetic Exchange NMR Spectroscopy. Angew. Chem. Int. Ed. 2011, 50, 4403-4406. [CrossRef]

38. Mundinger, S.; Jakob, U.; Bichovski, P.; Bannwarth, W. Modification and Optimization of the Bis-Picolylamide-Based Relay Protection for Carboxylic Acids to Be Cleaved by Unusual Complexation with Cu 2+ Salts. J. Org. Chem. 2012, 77, 8968-8979. [CrossRef]

39. Khan, K.M.; Rasheed, M.; Ullah, Z.; Hayat, S.; Kaukab, F.; Choudhary, M.I.; Ur-Rahman, A.; Perveen, S. Synthesis and in Vitro Leishmanicidal Activity of Some Hydrazides and Their Analogues. Bioorganic Med. Chem. 2003, 11, 1381-1387. [CrossRef]

40. Kudo, N.; Ito, A.; Arata, M.; Nakata, A.; Yoshida, M. Identification of a Novel Small Molecule That Inhibits Deacetylase but Not Defatty-Acylase Reaction Catalysed by SIRT2. Philos. Trans. R. Soc. B: Biol. Sci. 2018, 373, 20170070. [CrossRef]

41. Altıntop, M.D.; Ciftci, H.I.; Radwan, M.O.; Sever, B.; Kaplancıklı, Z.A.; Ali, T.F.S.; Koga, R.; Fujita, M.; Otsuka, M.; Zdemir, A. Design, Synthesis, and Biological Evaluation of Novel 1,3,4-Thiadiazole Derivatives as Potential Antitumor Agents against Chronic Myelogenous Leukemia: Striking Effect of Nitrothiazole Moiety. Molecules 2018, 23, 59. [CrossRef]

42. Bayrak, N.; Yıldırım, H.; Tuyun, A.F.; Kara, E.M.; Celik, B.O.; Gupta, G.K.; Ciftci, H.I.; Fujita, M.; Otsuka, M.; Nasiri, H.R. Synthesis, Computational Study, and Evaluation of In Vitro Antimicrobial, Antibiofilm, and Anticancer Activities of New Sulfanyl Aminonaphthoquinone Derivatives. Lett. Drug Des. Discov. 2017, 14. [CrossRef]

43. Ciftci, H.I.; Ozturk, S.E.; Ali, T.F.S.; Radwan, M.O.; Tateishi, H.; Koga, R.; Ocak, Z.; Can, M.; Otsuka, M.; Fujita, M. The First Pentacyclic Triterpenoid Gypsogenin Derivative Exhibiting Anti-ABL1 Kinase and Anti-Chronic Myelogenous Leukemia Activities. Biol. Pharm. Bull. 2018, 41, 570-574. [CrossRef] [PubMed]

44. Karabacak, M.; Altintop, M.D.; Çiftçi, H.I.; Koga, R.; Otsuka, M.; Fujita, M.; Özdemir, A. Synthesis and Evaluation of New Pyrazoline Derivatives as Potential Anticancer Agents. Molecules 2015, 20, 19066-19084. [CrossRef] [PubMed]

45. Ida, S.; Iwamaru, K.; Fujita, M.; Okamoto, Y.; Kudo, Y.; Kurosaki, H.; Otsuka, M. l-Histidyl-glycyl-glycyl-l-histidine. Amino-acid structuring of the bleomycin-type pentadentate metal-binding environment capable of efficient double-strand cleavage of plasmid DNA. Bioorganic Chem. 2015, 62, 8-14. [CrossRef] [PubMed]

46. Tanaka, A.; Radwan, M.O.; Hamasaki, A.; Ejima, T.; Obata, E.; Koga, R.; Tateishi, H.; Okamoto, Y.; Fujita, M.; Nakao, M.; et al. A Novel Inhibitor of Farnesyltransferase with a Zinc Site Recognition Moiety and a Farnesyl Group. Bioorganic Med. Chem. Lett. 2017, 27, 3862-3866. [CrossRef] [PubMed]

47. Koga, R.; Radwan, M.O.; Ejima, T.; Kanemaru, Y.; Tateishi, H.; Ali, T.F.S.; Ciftci, H.I.; Shibata, Y.; Taguchi, Y.; Inoue, J.-I.; et al. A Dithiol Compound Binds to the Zinc Finger Protein TRAF6 and Suppresses Its Ubiquitination. ChemMedChem 2017, 12, 1935-1941. [CrossRef] 
48. El-Shaheny, R.; Fuchigami, T.; Yoshida, S.; Radwan, M.O.; Nakayama, M. Complementary HPLC, in Silico Toxicity, and Molecular Docking Studies for Investigation of the Potential Influences of Gastric Acidity and Nitrite Content on Paracetamol Safety. Microchem. J. 2019, 150, 104-107. [CrossRef]

49. Nishimura, N.; Radwan, M.O.; Amano, M.; Endo, S.; Fujii, E.; Hayashi, H.; Ueno, S.; Ueno, N.; Tatetsu, H.; Hata, H.; et al. Novel p97/VCP inhibitor induces endoplasmic reticulum stress and apoptosis in both bortezomib-sensitive and-resistant multiple myeloma cells. Cancer Sci. 2019, 00,1-13. [CrossRef]

Sample Availability: Samples of the compounds are available from the authors.

(C) 2019 by the authors. Licensee MDPI, Basel, Switzerland. This article is an open access article distributed under the terms and conditions of the Creative Commons Attribution (CC BY) license (http://creativecommons.org/licenses/by/4.0/). 